NBER WORKING PAPER SERIES

CONSERVATION POLICIES:

WHO RESPONDS TO PRICE AND WHO RESPONDS TO PRESCRIPTION?

Casey J. Wichman

Laura O. Taylor

Roger H. von Haefen

Working Paper 20466

http://www.nber.org/papers/w20466

\author{
NATIONAL BUREAU OF ECONOMIC RESEARCH \\ 1050 Massachusetts Avenue \\ Cambridge, MA 02138 \\ September 2014
}

Partial support for this research by the Center for Environmental and Resource Economic Policy (NC State University) and the Environmental Finance Center (University of North Carolina, Chapel Hill) is gratefully acknowledged. The authors thank participants at the following workshops and conferences for helpful suggestions: Camp Resources, Appalachian State University, the Association of Public Policy Analysis and Management, the NC Water Resources Research Institute, the Property and Environment Research Center, and the Agricultural and Applied Economics Association Annual Meetings. The views expressed herein are those of the authors and do not necessarily reflect the views of the National Bureau of Economic Research.

NBER working papers are circulated for discussion and comment purposes. They have not been peerreviewed or been subject to the review by the NBER Board of Directors that accompanies official NBER publications.

(C) 2014 by Casey J. Wichman, Laura O. Taylor, and Roger H. von Haefen. All rights reserved. Short sections of text, not to exceed two paragraphs, may be quoted without explicit permission provided that full credit, including $(\mathcal{C}$ notice, is given to the source. 
Conservation Policies: Who Responds to Price and Who Responds to Prescription?

Casey J. Wichman, Laura O. Taylor, and Roger H. von Haefen

NBER Working Paper No. 20466

September 2014

JEL No. D12,H42,L51,L95,Q25

\section{$\underline{\text { ABSTRACT }}$}

The efficiency properties of price and non-price instruments for conservation in environmental policy are well understood. Yet, there is little evidence comparing the effectiveness of these instruments, especially when considering water resource management. We exploit a rich panel of residential water consumption to examine heterogeneous responses to both price and non-price conservation policies during times of drought while controlling for unobservable household characteristics. Our empirical models suggest that the burden of pricing policies fall disproportionately on low-income households and fail to reduce consumption among households who generally are large consumers of water. However, prescriptive policies such as restrictions on outdoor water use result in uniform responses across income classes while simultaneously targeting reductions from households with irrigation systems or historically high consumption.

Casey J. Wichman

Departmennt of Agricultural and Resource Economics

University of Maryland

2200 Symons Hall

College Park, MD 20742

wichman@umd.edu

Laura O. Taylor

Department of Agricultural

and Resource Economics

North Carolina State University

University Box 8109

Raleigh, NC 27695-8109

laura_taylor@ncsu.edu
Roger H. von Haefen

Department of Agricultural and Resource Economics

4338 Nelson Hall

North Carolina State University Box 8109

Raleigh, NC 27695-8109

and NBER

roger_von_haefen@ncsu.edu 


\title{
CONSERVATION POLICIES: WhO RESPONDS TO PRICE AND WHO RESPONDS TO PRESCRIPTION?
}

\author{
Casey J. Wichman, Laura O. Taylor, and Roger H. von Haefen ${ }^{1}$
}

August 2014

\begin{abstract}
The efficiency properties of price and non-price instruments for conservation in environmental policy are well understood. Yet, there is little evidence comparing the effectiveness of these instruments, especially when considering water resource management. We exploit a rich panel of residential water consumption to examine heterogeneous responses to both price and non-price conservation policies during times of drought while controlling for unobservable household characteristics. Our empirical models suggest that the burden of pricing policies fall disproportionately on low-income households and fail to reduce consumption among households who generally are large consumers of water. However, prescriptive policies such as restrictions on outdoor water use result in uniform responses across income classes while simultaneously targeting reductions from households with irrigation systems or historically high consumption.
\end{abstract}

JEL Codes: Q25, D12, H42, L51, L95

Keywords: Water demand, non-price policies, price regulation, conservation, drought

\section{Introduction}

Although prescriptive policies are commonly employed by resource managers to encourage conservation, economists tend to advocate for pricing mechanisms to achieve environmental goals since they are typically more efficient. However, many environmental management contexts involve resources whose prices are regulated by utility commissions or federal oversight. As such, the use of pricing tools to encourage conservation is politically challenging. This is particularly true in the case of water

\footnotetext{
${ }^{1}$ Wichman: Dept. of Agricultural and Resource Economics, University of Maryland, College Park, wichman@umd.edu. Taylor and von Haefen: Dept. of Agricultural and Resource Economics and Center for Environmental and Resource Economic Policy, North Carolina State University, laura_taylor@ncsu.edu and rhhaefen@ncsu.edu, respectively. Partial support for this research by the Center for Environmental and Resource Economic Policy (NC State University) and the Environmental Finance Center (University of North Carolina, Chapel Hill) is gratefully acknowledged. The authors thank participants at the following workshops and conferences for helpful suggestions: Camp Resources, Appalachian State University, the Association of Public Policy Analysis and Management, the NC Water Resources Research Institute, the Property and Environment Research Center, and the Agricultural and Applied Economics Association Annual Meetings.
} 
resource management. Efficiency would dictate that price reflects long-run marginal cost of provision, including scarcity rents, which is typically markedly higher than regulated market prices (Mansur and Olmstead, 2012). As such, non-price strategies, also referred to as prescriptive policies, have become popular demand management tools for water conservation during periods of drought in which the short-run reliability of water resource systems are at risk. These strategies can take the form of restrictions on outdoor water use (Castledine et al., 2014; Renwick and Green, 2000), information campaigns (Coleman, 1999), social comparisons (Ferraro and Price, 2013), or financial incentives for technology adoption (Bennear et al., 2013; Renwick and Archibald, 1998). ${ }^{2}$

Despite growing usage of non-price policies in environmental contexts, and a corresponding literature measuring their effectiveness, there is little evidence of the relative merits of pricing versus prescriptive restrictions using household-level panel that allows consideration of both policy types simultaneously, and we have even less evidence about the heterogeneity in responsiveness to these conservation tools across households. These responses are important to understand because water utilities and policy makers are concerned about the regressive incidence of pricing policies on lower income households. Further, an important goal of water utilities is to manage the use of households in the upper-tail of the consumption distribution as a means to help reduce water infrastructure over-capitalization. While efficient pricing such as dynamic increasing block rates could address these concerns, as mentioned above they are not generally politically feasible.

In this research, we provide evidence on important observable household characteristics that influence responsiveness to demand-side management policies, while

\footnotetext{
${ }^{2}$ Select examples of these tools being utilized in the energy sector to manage household demand include social comparisons (Alcott 2011) and financial incentives for technology adoption (Alberini et al. 2013).
} 
econometrically controlling for unobservable household attributes. Olmstead and Stavins (2009) lay out an exhaustive comparison of price and non-price policies and conclude that neither prices nor prescriptive policies are superior in their distributional bona fides, despite prices being a more cost-effective solution. However, we provide strong empirical evidence that prescriptive conservation policies display more palatable distributional features than price regulation.

Our analysis exploits a rich dataset of water monthly consumption for 1,727 households across six municipalities in North Carolina. The data span a two-and-a-half year period that includes months in which North Carolina was in a severe drought and months in which there were normal conditions. There is variation in drought conditions, price and non-price policies both within the municipalities over time and across municipalities. Further, for each household we observe the household's income, lot-size and whether or not an irrigation system is present. Given the long panel and rich variation in key variables, we are able to identify price and non-price policy responses that reflect month-to-month decisions within a household while controlling for time-invariant unobservable household characteristics that might bias results.

Results indicate that mandatory (voluntary) prescriptive policies focused on outdoor watering restrictions achieve approximately a ten percent (three percent) reduction in aggregate demand. Given the inelastic price responsiveness of households, an average price increase of more than $30 \%$ would be required to achieve the same ten percent reduction in water use that the prescriptive mandatory policies achieved. This price increase would imply a 20 percent increase in the average customer's monthly expenditures on water. 
Additionally, results from our empirical models suggest that there is important heterogeneity in how households respond to price. Overall, our results suggest that when pricing mechanisms are implemented to affect consumption patterns, the conservation burden falls primarily on lower-income households. The evidence suggests that highincome households are significantly less responsive to price, and households with irrigation systems are found to be completely unresponsive to the price changes that occurred during our sample period. On the other hand, there is a notable lack of heterogeneity among households in their responsiveness to voluntary and mandatory prescriptive policies with the important exception of households with irrigation systems and/or those that are large-volume consumers. Households with irrigation systems and households in the upper $20^{\text {th }}$ percentile of average consumption in their municipality are found to be almost twice as responsive to mandatory policies than other households. These results are robust to different model specifications and various definitions of key variables.

The remainder of the paper is as follows. In the next section, we motivate our empirics by highlighting the unique data used in the analysis. The third section presents empirical models of residential water demand that incorporate household heterogeneity explicitly and presents key empirical results and sensitivity analyses. In the final section, we discuss the policy implications of our results and offer concluding remarks.

\section{Data}

Thirty consecutive months of household-level billing data are coupled with survey responses for 1,727 households in six municipalities across North Carolina. The data 
have rich spatial and temporal variation in weather conditions, water rate structures, household water consumption, and demand-side management programs. We describe each of these features below.

Household monthly water use is observed for the period July 2006 through December 2008, which spans two summers with persistent drought conditions and one summer with normal conditions. The six municipalities providing water utility billing data are listed in Table 1 along with summary statistics for the households surveyed in each community. The municipalities span the three geographic regions of North Carolina and the average weather and growing conditions varies across these municipalities as a result. Fayetteville and Greenville are in the coastal plan region of the state and are the warmest with average July maximum temperatures of 90 degrees. Hendersonville is in the mountainous, western part of the state and is the coolest municipality with average July maximum temperatures of 84 degrees. Charlotte, High Point, and Chapel Hill are in the central Piedmont region of the state and have weather closer to that of coastal plain, with average July maximum temperatures between 88 and 90 degrees.

Monthly water billing data including water and sewer usage were obtained for singlefamily, detached housing in each of these municipalities. A random sample of households with complete billing data was selected for a telephone interview that collected information on household demographics and irrigation habits. Telephone interviews took place during August and September 2009 and were conducted by Agricultural Statistics 
Division of the N.C. Department of Agriculture and Consumer Services. ${ }^{3}$ As indicated in Table 1, between 225 and 388 surveys are available for each municipality. ${ }^{4}$

\subsection{Household Characteristics}

Overall, the survey respondents are high-income households. As indicated in Panel A of Table 1, the sample mean income is $\$ 123,034$ and the median is $\$ 112,500 .^{5}$ Mean income varies by municipality, ranging from $\$ 88,622$ in Fayetteville to $\$ 183,987$ in Chapel Hill. Overall, the households in our sample have substantially higher income than the median for N.C. in $2010(\$ 45,570)$. However, our sample is $100 \%$ homeowners and median income for just homeowners in urbanized areas is not readily available. It is possible to compare home values between our sample and the median within each municipality's boundary as reported by Census. As reported in Table 1, median home values in our sample vary from $\$ 187,500$ in Fayetteville and High Point to $\$ 325,000$ in Chapel Hill. For five of the six municipalities, the median home value for the sample is on average approximately $30 \%$ higher than Census reported median home value for the entire municipality. The exception is Chapel Hill in which the median value for our sample of homes is $9 \%$ lower than the median home value for all of Chapel Hill.

Mean home square footage is approximately 2,700 square feet across each of our municipalities, and the mean lot size is 0.6 acres, with the exception of Hendersonville, which has an average of 1.1 acre per household. The average household size in the

\footnotetext{
${ }^{3}$ Phone numbers were purchased from InfoUSA, a private vendor since the participating water utilities generally did not maintain phone numbers for their customers.

${ }^{4}$ Note, the billing and survey data are drawn from each water utility service area and thus encompasses a broader population than just residents from within the city limits.

${ }^{5}$ Due to item non-response, household income data is taken from InfoUSA, the vendor providing household phone numbers. These income data are more disaggregated than survey-reported income.
} 
sample varies from 2.34 to 2.86 individuals per home, while the average for North Carolina during this time period was 2.47 individuals per dwelling unit of any type.

\subsection{Water Consumption and Pricing}

Panel B of Table 1 presents summary statistics for household water use. The mean monthly household consumption is 5,289 gallons per month for the entire sample, which is very close to the average consumption in N.C. of 5,259 gallons per month per household. ${ }^{6}$ The distribution of water use among households is right-skewed as indicated by medians being less than means for all municipalities. As indicated in the last row of Panel $\mathrm{B}$, the $90^{\text {th }}$ percentile of monthly water use among our sample is nearly double the magnitude of mean monthly use. ${ }^{7}$ Across municipalities, residents in Charlotte consume the most water on average, and Hendersonville consumes the least.

Panel $\mathrm{C}$ in Table 1 reports the prices paid by utility customers per 1,000 gallons consumed. Each utility bills customers on a monthly basis and combines water and sewer charges in one bill. Average and marginal volumetric charges for combined water and sewer use are constructed for each household in each month based on their ex post water consumption and published utility rate sheets. Four municipalities have an increasing block rate structure during at least part of the study period and two have a flatrate structure. Because all municipalities charge a base (fixed) service fee for water and

\footnotetext{
${ }^{6}$ Average consumption for N.C. is constructed using an estimated per-capita consumption of 70 gallons per day in 2005 (Kenny, et al., 2009).

${ }^{7}$ Several municipalities in our study round consumption to the nearest thousand gallons each month for billing purposes. This factor explains the prevalence of 2,000 gallons as the $10^{\text {th }}$ percentile of consumption for the sample.
} 
sewer use, the average and marginal prices for water consumed diverge in all communities, not just those with increasing block rates. ${ }^{8}$

As indicated in Panel $\mathrm{C}$, there is considerable heterogeneity in water prices across the municipalities. Mean average price across municipalities varies from $\$ 6.78$ to $\$ 13.06$ per thousand gallons, with Charlotte customers paying the lowest average prices and customers in Hendersonville paying the highest. The differences in average prices are primarily driven by the wide variety in the fixed base service fee across municipalities ( $\$ 3.49$ to $\$ 17.95$, see the third row of Panel C). Fixed fees are not reflected in marginal prices, and thus the variation in the mean marginal price paid is less than that of average price, varying from $\$ 6.70$ to $\$ 10.03$ across municipalities.

Figure 1 indicates the variability in water consumption over the study period. As shown, Charlotte has visibly higher average per capita consumption than the rest of the municipalities, with large peaks in the summer of both 2006 and 2007. Peak summer consumption in Chapel Hill is somewhat smaller than Charlotte in 2006 and 2007, but is the lowest among all municipalities in 2008. During summer 2008, it is Greenville that exhibits the largest summer peak. Fayetteville tracks with Greenville in early summer, but then reduces average consumption by mid-summer and is among the lowest for the sample during late summer, 2008. Overall, there is a clear reduction in the peak for the summer of 2008 for all of the utilities. In the winter months, average consumption in Charlotte is consistently higher than the remaining five municipalities who all have similar consumption levels.

\footnotetext{
${ }^{8}$ The two municipalities with flat rates actually had in place a declining rate structure for at least part of the study period. However, the first block was so large (e.g., up to 40,000 gallons per month) that nearly $100 \%$ of their customers fell well within the first block. Thus, we treat these two communities as having a flatrate structure.
} 
Figure 2 presents the variation in prices paid by water customers over the study period. As shown in Panel A, Charlotte customers paid the lowest average prices while Chapel Hill, High Point, and Hendersonville customers paid the highest average prices. An overall increasing trend in average prices across all municipalities is evident as well. This increasing trend is driven by changes in rate structures implemented by each utility over the study period. All of the municipalities increased their prices in some way over the study period. In particular, Chapel Hill customers faced a uniform water rate until July 2007, after which an increasing block rate structure was adopted. In addition to adopting an increasing block rate, Chapel Hill also implemented seasonal and droughtinduced surcharges in their rate schedule.

Panel $\mathrm{B}$ in Figure 2 presents mean marginal prices over time and indicates that Hendersonville exhibits the consistently highest marginal price with little variation over time, while Chapel Hill is the most variable with mean marginal prices peaking higher than any other municipality due to an aggressive drought pricing mechanism. Greenville and Charlotte display the lowest marginal prices, reflecting similar trends to average prices, though Charlotte's introduction of increasing block rates in the summer of 2008 raises the observed marginal price in the later months. Overall, the comparison of Panels $\mathrm{A}$ and $\mathrm{B}$ provides an indication that average prices are more time-variant than marginal prices within a municipality.

\subsection{Drought and Policy Parameters}

An integral part of this research is the presence of significant drought conditions throughout North Carolina beginning in the summer of 2007. Table 2 presents a 
summary index of monthly drought conditions in each municipality throughout the study period, along with an indicator of whether voluntary (V) or mandatory (M) watering restrictions were in place for the majority of that month. An average over of the weekly drought conditions is computed to determine the average status for each month. Weekly drought conditions are described by one of six categories ranging from "normal conditions" $(=0)$ to "exceptional drought" $(=5)$, the most severe category possible. ${ }^{9}$ Thus, if in all weeks of a month a municipality is recorded as having "exceptional drought," the index for that month would be 5.0. Average conditions over the month are represented in Table 2 by shades of gray in which the darkest shade with dots indicates a month in which at least half the weeks were categorized as "extreme" or "exceptional drought" and diagonal lines indicate a month in which all weeks were classified as having exceptional drought. No color in Table 2 indicates a month in which the average drought condition across weeks in that month is less than 1.0 (see footnote 1 , Table 2 for more details).

As indicated in Table 2, by September 2007 all regions were in severe drought and were subsequently elevated to exceptional drought status, the most severe classification by December 2007. The drought conditions persisted until April 2008, and gradually returned to normal levels afterwards.

Water utilities in North Carolina responded to the 2007 drought by encouraging residential conservation through voluntary or mandatory outdoor watering restrictions. Across municipalities, voluntary restrictions typically took the form of asking customers to limit outdoor lawn and garden watering to $2-3$ days a week in a pattern determined by

\footnotetext{
${ }^{9}$ Specifically, the categories are $0=$ normal conditions, $1=$ abnormally dry, $2=$ moderate drought, $3=$ severe drought, $4=$ extreme drought, and $5=$ exceptional drought. The definition of each drought category is available from the U.S. Drought Monitor at http://droughtmonitor.unl.edu/monitor.html, last accessed February 19, 2012.
} 
their street address and/or watering only late in the evening or early morning. In addition, customers were also asked to limit other nonessential uses of water such as car washing and home/driveway washing. Mandatory restrictions were generally of the same form as the voluntary restrictions, but in some instances the austerity of the actions were increased, as described below.

Table 2 presents the months when voluntary and mandatory restrictions were in place and Table 3 summarizes the restrictions broadly for each municipality. As indicated in Table 2, all municipalities in our sample employed either voluntary or mandatory restrictions during the study period, while Greenville (Fayetteville) never implemented a voluntary (mandatory) policy. Two of the six municipalities (Fayetteville and Charlotte) implemented mandatory restrictions as early as May 2007 and September 2007, respectively, and kept them in place through the rest of our study period. ${ }^{10}$

During the peak growing seasons, Charlotte and Fayetteville implemented similar mandatory restrictions. In summer 2007, both these municipalities limited outdoor lawn watering to two days per week. In summer 2008, Charlotte further reduced this to one day per week while Fayetteville continued to allow two days per week. High Point and Chapel Hill implemented mandatory restrictions on outdoor water use, but not during the primary growing season or for only one month in the case of High Point. Finally, Hendersonville implemented mandatory restrictions during the last two months of summer 2008 that disallowed watering of lawns, while Greenville never moved from voluntary into mandatory restrictions. Overall, there is some degree of heterogeneity in the austerity of watering restrictions and enforcement across municipalities. However,

\footnotetext{
${ }^{10}$ Since the 2002 drought, Fayetteville's default drought policy is to implement mandatory restrictions corresponding to the irrigation months (May-September).
} 
we do not directly model this heterogeneity since policies are generally similar the majority of the time. In the few instances that very strict mandatory restrictions were put in place (i.e., a complete ban on outdoor watering), the restriction was exceptionally short-lived or during off-peak seasons where outdoor watering is minimal anyway.

\section{Empirical strategy and results}

To identify water consumption responsiveness to price and prescription policies, we develop a panel instrumental variables (IV) model that addresses price endogeneity and incorporates unobserved household heterogeneity through household-specific fixed effects. ${ }^{11}$ Our baseline specification takes the form:

$$
\ln \left(\mathrm{q}_{\mathrm{ikt}}\right)=\beta_{1} \ln \left(\widehat{\mathrm{AP}}_{\mathrm{ikt}-1}\right)+\beta_{2} \text { Voluntary }_{\mathrm{kt}}+\beta_{3} \text { Mandatory }_{\mathrm{kt}}+\mathrm{W}_{\mathrm{kt}} \gamma+\theta_{\mathrm{t}}+\alpha_{\mathrm{i}}+\varepsilon_{\mathrm{ikt}},
$$

where the natural $\log$ of monthly water consumption ( $\left.\mathrm{q}_{\mathrm{ikt}}\right)$ for household $\mathrm{i}$ in municipality $\mathrm{k}$ in month $\mathrm{t}$ is regressed on the instrumented natural log of the average price paid per 1,000 gallons of water in the previous month $\left(\mathrm{AP}_{\mathrm{ikt-1}}\right)$, indicator variables for whether or not a voluntary or mandatory water restriction policy was in place during the month (Voluntary $\mathrm{kt}_{\mathrm{k}}$ and Mandatory $\mathrm{k}_{\mathrm{k}}$, respectively), a vector of six covariates capturing weather conditions over the month $\left(\mathrm{W}_{\mathrm{kt}}\right)$, and month and household fixed effects $\left(\theta_{\mathrm{t}}\right.$ and $\alpha_{\mathrm{i}}$, respectively). The random error term is given by $\varepsilon_{\text {ikt. }}$ Since Equation (1) does not account for the upward sloping demand inherent in block pricing, we follow Olmstead

\footnotetext{
${ }^{11}$ All models were also estimated in a random effects framework to exploit cross-sectional variation in the data and check the robustness of results. A series of Hausman tests rejects the hypothesis that the random effects estimator is consistent for all but the simplest specification with a p-value less than 0.01 . The consistency of the within-estimator and ability to control for unobserved household characteristics make the fixed effects model the preferred specification. Random effects estimates are available from the authors upon request.
} 
(2009) by instrumenting the natural log of lagged average price by the natural log of marginal prices at arbitrary levels of consumption as follows:

$$
\ln \left(\hat{\mathrm{p}}_{\mathrm{ikt}-1}\right)=\sum_{\mathrm{j}=1}^{\mathrm{J}} \delta_{\mathrm{j}} \ln \left(\mathrm{MP}_{\mathrm{kt}-1}^{\mathrm{j}}\right)+\pi \ln \left(\text { base }_{\mathrm{kt}-1}\right)+\theta_{\mathrm{t}}+\alpha_{\mathrm{i}}+\eta_{\mathrm{ikt}},
$$

where $\mathrm{MP}_{\mathrm{kt}-1}^{\mathrm{j}}$ is the marginal price per thousand gallons for the next unit of water consumed for a monthly consumption level at $\mathrm{j}$ thousand gallons. We use the instrument set $\mathrm{j}=\{1,3,5,7,9,12,15,20\}$ to capture variation in rate structures among the distribution of consumption, while allowing all municipalities to have the same number of instruments regardless of the number of price tiers observed for a particular municipality at any point in time. ${ }^{12}$ Also, base $\mathrm{kt}-1$ is the base service fee for water and sewer use, and all else is defined as in Equation (1). ${ }^{13}$ The rationale for these instruments is that they are correlated with the price a household pays since they are representative of the entire rate structure for a particular utility, however the individual household's consumption choice does not affect the utility's rate schedule. Kleibergen-Paap Wald Fstatistics are computed to test the hypothesis that the instruments in the first-stage regression are jointly significant predictors of average price in the presence of withinhousehold error correlation and clustered standard errors, and are all significant at the $1 \%$ level (Kleibergen and Paap, 2006).

The first two panels of Table 4 provide definitions and summary statistics for each of the variables included in equations (1) and (2). Average price is the ex post average price calculated by dividing the total billed amount by total consumption. Average rather than marginal prices are used in our main analysis for several reasons. First, it is likely that

\footnotetext{
${ }^{12}$ Models were estimated with several sets of instruments corresponding to different consumption levels and different numbers of marginal prices; coefficient estimates for average price in the second-stage regression are stable across different instrument choices in the first-stage.

${ }^{13}$ All models were estimated using the "xtivreg2" routine in Stata 11.2 with standard errors robust to heteroskedasticity and clustered at the household level (Schaffer, 2005).
} 
consumers do not know their precise level of consumption throughout the billing period and, hence, do not know the marginal price being charged at any point in time. Thus it is likely that households respond to their total bill from the previous month when considering altering planned water consumption in the current period, indicating an average price concept is appropriate. This concept is supported by Wichman (2014) and Ito (2014) who both use quasi-experimental research designs and find that consumers respond to average price rather than marginal price when facing tiered rate structures. From an econometric standpoint, assuming that consumer's respond to their previous bill also allows for the avoidance of contemporaneous correlation with consumption by incorporating lagged average price in the econometric specification (Wichman, 2014). Further, average prices exhibit stronger temporal variation than marginal prices in our sample, which improves identification in empirical models that control for unobserved, time-invariant factors at the household level. ${ }^{14}$

As indicated in Panel B of Table 4, voluntary watering restrictions were in place 15\% of the months in our sample and mandatory restrictions were in place $32 \%$ of the months. Weather covariates included in the model $\left(\mathrm{W}_{\mathrm{kt}}\right)$ include monthly rainfall, mean monthly maximum temperature, a quadratic term for each of these two variables, and an interaction term between monthly rainfall and mean monthly maximum temperature. These weather variables are included because water usage is driven by current weather conditions while drought conditions (and associated policy instruments) are the result of

\footnotetext{
${ }^{14}$ Models were also estimated assuming households respond to the marginal price of the last 1,000 gallons consumed controlling for infra-marginal rate changes affecting virtual income according to Taylor-Nordin models of demand with non-linear budget constraints (c.f., Olmstead, 2009). Estimated price elasticities are generally similar when marginal price is included in the model instead of average price. Importantly, results regarding the impacts of voluntary and mandatory prescriptive policies are largely invariant to the choice of average versus marginal price. As such, we report only models using average price. The full set of results using marginal price are available from the authors upon request.
} 
cumulative weather, storage, and demand patterns. In other words, it is possible to have a reasonably wet month (with little irrigation need), but be in category four or five drought in that month. As such, current weather conditions are important determinants of water use and are not collinear with drought (or policy) status.

Equation (1) estimates the average effect of voluntary and mandatory restrictions across all municipalities. However, as noted earlier, the municipalities differ in the precise mix of policies implemented. As such, we estimate municipality-specific policy effects as follows:

$$
\begin{gathered}
\ln \left(\mathrm{q}_{\mathrm{ikt}}\right)=\beta_{1} \ln \left(\widehat{\mathrm{AP}}_{\mathrm{ikt}-1}\right)+\beta_{2} \text { Voluntary }_{\mathrm{kt}}+\sum_{\mathrm{k}=1}^{4} \beta_{2 \mathrm{k}} \text { Voluntary }_{\mathrm{kt}} * \text { Muni }_{\mathrm{k}}+ \\
\beta_{3} \text { Mandatory }_{\mathrm{kt}}+\sum_{\mathrm{k}=1}^{4} \beta_{3 \mathrm{k}} \text { Mandatory }_{\mathrm{kt}} * \text { Muni }_{\mathrm{k}}+\mathrm{W}_{\mathrm{kt}} \gamma+\theta_{\mathrm{t}}+\alpha_{\mathrm{i}} \varepsilon_{\mathrm{ikt}},
\end{gathered}
$$

where voluntary and mandatory policies are now interacted with dummy variables for each municipality, Muni $\mathrm{k}_{\mathrm{k}}$, and all else is as defined for equation (1). While the demand management programs are broadly similar across municipalities, the idiosyncratic features of each municipality's voluntary and mandatory programs, such as the precise mix of prescriptions implemented and regulatory enforcement levels, are captured in $\beta_{2 \mathrm{k}}$ and $\beta_{3 \mathrm{k}}$, respectively. Recall that Fayetteville never implemented a voluntary policy and Greenville never implemented a mandatory policy, thus these municipalities are not interacted to obtain municipal-specific policy effects. We choose Hendersonville to serve as the omitted category.

Heterogeneity across households is introduced to the model by interacting a vector of household characteristics, $\mathrm{HH}_{\mathrm{jik}}$, with both price and non-price policies: ${ }^{15}$

\footnotetext{
${ }^{15}$ When estimating equation (4), the demographic interactions with average price also provide additional instruments in the first stage regression presented in equation (2). Specifically, the set of marginal prices and base charges in equation (2) is interacted with each household characteristic included in equation (4).
} 


$$
\begin{gathered}
\ln \left(\mathrm{q}_{\mathrm{ikt}}\right)=\beta_{1} \ln \left(\widehat{\mathrm{AP}}_{\mathrm{ikt}-1}\right)+\sum_{j=1}^{5} \beta_{1 \mathrm{j}} \ln \left(\widehat{\mathrm{AP}}_{\mathrm{ikt}-1}\right) * \mathrm{HH}_{\mathrm{jik}}+\mathrm{W}_{\mathrm{kt}} \gamma \\
+\beta_{2} \operatorname{Vol}_{\mathrm{kt}}+\sum_{\mathrm{k}=1}^{4} \beta_{2 \mathrm{k}} \operatorname{Vol}_{\mathrm{kt}} * \mathrm{Muni}_{\mathrm{k}}+\sum_{\mathrm{j}=1}^{5} \beta_{3 \mathrm{k}} \operatorname{Vol}_{\mathrm{kt}} * \mathrm{HH}_{\mathrm{jik}} \\
+\beta_{3} \operatorname{Mand}_{\mathrm{kt}}+\sum_{\mathrm{k}=1}^{4} \beta_{3 \mathrm{k}} \operatorname{Mand}_{\mathrm{kt}} * \operatorname{Muni}_{\mathrm{k}}+\sum_{\mathrm{j}=1}^{5} \beta_{4 \mathrm{j}} \operatorname{Mand}_{\mathrm{kt}} * \mathrm{HH}_{\mathrm{jik}}+\theta_{\mathrm{t}}+\alpha_{\mathrm{i}}+\varepsilon_{\mathrm{ikt}} .
\end{gathered}
$$

Household characteristics included in $\mathrm{HH}_{\mathrm{ik}}$ include income, lot size, the presence of an in-ground irrigation system, and two categorical variables that indicate whether or not a household has historically very high or very low consumption patterns.

Panel C of Table 4 presents the variables included in the vector household characteristics assumed to influence consumption, $\mathrm{HH}_{\mathrm{j}}$. Specifically, an indicator variable for whether the household's income was above $\$ 75,000$ per annum is included along with three categorical variables indicating the lot size (small lots are the category left out of the model) and whether the household has an in-ground irrigation system. In addition, we also include variables that describe each household's average water consumption pattern prior to any prescriptive demand-side management policies restrictions being in place (see Panel C, Table 4). ${ }^{16}$ Specifically, we identify households whose average consumption is in the upper $20 \%$ or lower $20 \%$ of the distribution for their municipality prior to watering restrictions being enacted. The response of high-volume water users to both price and prescriptive management tools is of particular interest because these households have a higher degree of discretionary water use and are

\footnotetext{
${ }^{16}$ There is no period in our data in which Fayetteville households had not already been exposed to permanent mandatory watering restrictions. For purposes of computing consumptive groups, we treat these households as if they were introduced to non-price policies in August 2007 to be consistent with other municipalities. Note also that Charlotte implemented voluntary restrictions in June 2007, so we restrict the classification of high/low users within this municipality to the period prior to June 2007.
} 
presumably less sensitive to price incentives. ${ }^{17}$ Managing the demands of high-volume users is thought to be a key component of reducing peak-demands, which is an important goal for water managers who seek to avoid over-capitalization in the delivery system. In this effort, we explore the heterogeneity in response to prices and prescription policies by "consumptive class" by modeling average consumption in the pre-policy period as a time-invariant household characteristic that is incorporated in the vector $H H_{j i k}$ in equation (4). ${ }^{18}$

\section{$\underline{3.1 \text { Results }}$}

Select coefficients for the models in equations (1), (3) and (4) are presented in Table 5. Not reported for succinctness are weather covariates or month and household fixed effects. ${ }^{19}$ The first column in Table 5 presents the results from estimation of equation (1) and suggests an average price elasticity across the entire sample of -0.28 , which compares favorably with previous estimates in the literature. Espey et al. (1997) conduct a meta-analysis of water price elasticity estimates from across the U.S., and find an overall mean of -0.51 with a short-run median of -0.38 , roughly consistent with our estimates. $^{20}$ Our results also fall within the range of price elasticities estimated in more

\footnotetext{
${ }^{17}$ Although Ferraro and Price (2013) show that water customers with historical consumption above the mean display a stronger response to a conservation message that appealed to social norms, we have little evidence on the responsiveness of high-volume users to non-price policies outside this specific example.

${ }^{18}$ Of course, we recognize that including a function of the dependent variable as a regressor potentially introduces endogeneity into our estimating equation. Thus, we present results for estimation of equation (4) both with and without covariates describing average household consumption prior to prescriptive management tools being in place. We also considered a quantile regression approach (accounting for timeinvariant unobservables and endogenous covariates in the spirit of Harding and Lamarche (2009)) and the results were largely consistent with the heterogeneity models presented in this paper. See Wichman (2011). ${ }^{19}$ Weather covariates had the expected sign and significance in all models. Full results are available from the authors. The first-stage IV regression results (equation 2) are also available from the authors upon request.

${ }^{20}$ Dalhuisen et al. (2003) re-examine the Espey et al. findings with a larger set of data and find that $90 \%$ of price elasticity estimates fall between 0 and -0.75 .
} 
recent literature that conditions on seasonal and household heterogeneity (e.g., Baerenklau et al. 2014, Wichman 2014, Klaiber et al. 2014, Mansur and Olmstead 2011, Nataraj and Hanemann 2011, Halich and Stephenson 2009, Olmstead 2009, and Olmstead et al. 2007). These studies report a price elasticity range between -0.12 and 1.93. However, estimates from these recent studies are concentrated within the inelastic range and the modal estimates lie roughly between -0.3 and -0.5 , which is similar to our range, albeit slightly higher. Our relatively smaller elasticity estimates can be explained by the fact that we are estimating short-run responses to changes in price within a household, controlling for time-invariant household characteristics. The extent to which estimates from other research are higher may reflect correlation between water use and unobservable household characteristics not included in those models. Thus, research that uses cross-sectional variation in price to identify price elasticities may overstate the average impact of price changes for a given household.

The estimated average response to voluntary and mandatory watering restrictions across the entire sample (Column 1 , Table 5) was a $3.2 \%$ and $9.2 \%$ reduction in water consumption, respectively, and both are significant at the $1 \%$ level. These estimates imply that after controlling for observable weather variables and unobserved timeinvariant characteristics at the month and household level, prescriptive conservation policies have a significant negative effect on residential water demand. Our findings are generally consistent with recent research. For example, Halich and Stephenson (2009) explore changes in municipal-level average water use when voluntary and mandatory conservation policies were implemented in 21 municipalities in Virginia. Their results indicate that voluntary restrictions could reduce consumption by as much as seven 
percent, but they also find no response to voluntary restrictions in some communities. Mandatory restrictions were found to reduce consumption by between four and 22 percent. The variation within each policy's effectiveness is attributed to varying levels of municipal effort in disseminating information and varying levels of enforcement.

Several studies have explored non-price policy effectiveness in the western U.S. using aggregate municipal (or utility-level) water consumption data. For example, Michelsen et al. (1999) analyze water use in seven municipalities throughout the Southwest and find that non-price programs reduced water demand between one and four percent. However, Michelsen et al. do not distinguish between voluntary and mandatory programs even though both seem to have been in place at some point over their study period. By contrast, Renwick and Green (2000) find quite large impacts of non-price programs on average water demand in eight California municipalities, ranging from an eight percent reduction in average water use when information campaigns are used to a 29 percent reduction in average water use when watering restrictions are in place. ${ }^{21}$ As a counterpoint to Halich and Stephenson (2009), Renwick and Green (2000), and Renwick and Archibald (1998), our relatively smaller estimates capture the effect of variation of policies within a household, which again suggests that unobserved heterogeneity may bias policy estimates away from zero. In addition, there are significant differences in the study areas. It may not be appropriate to compare conservation policies in a humid, but

\footnotetext{
${ }^{21}$ Similarly, Renwick and Archibald (1998) estimate that mandatory restrictions in coastal California resulted in a $16-28 \%$ reduction in average municipal water use that varied by the average housing density within the service area, which the authors take to be a proxy for irrigation preferences.
} 
drought-prone area such as North Carolina, to that of arid communities in the Southwest or coastal California. ${ }^{22}$

Estimation results for the model in equation (3) that incorporates municipal-specific average effects are presented in Table 5, Column (2), Panel B. The municipality interaction term captures the average effect of the idiosyncratic components of each municipality's voluntary or mandatory watering restriction program, and results indicate that there is considerable heterogeneity in household responses to these prescriptive programs between municipalities. With respect to voluntary policies, results indicate that households in Hendersonville (the municipality left out of the model), Greenville and High Point all had quantitatively similar responses to voluntary restrictions, reducing use approximately 4.5 percent. Chapel Hill residents were most responsive to voluntary policies, reducing water consumption approximately 12.5 percent during months in which these policies were in place, and the models indicate that households in Charlotte increased their water consumption by approximately 5.4 percent during months when voluntary restrictions were in place. The positive relationship between water consumption and voluntary restrictions for Charlotte is consistent across all models. One explanation for these puzzling results could be that Charlotte's voluntary program was initiated in June 2007 and continued only through August, 2007. These months were the very beginning of the drought, and water scarcity had not yet become severe nor consistent state-wide (see Table 2). Thus, the perception (or knowledge) of households

\footnotetext{
${ }^{22}$ In related work, Castledine et al. (2014) exploit daily household-level water consumption in Reno, Nevada and find that day-of-week mandatory watering restrictions result in "rigidity penalties" of 20 to 25 percent of weekly water use. In other words, households choose to irrigate on their assigned days, days regardless of prevailing weather conditions and irrigate suboptimally as a result. The authors conclude that rigid day-of-the-week irrigation restrictions result in higher water use peaks and less efficient average water use than what would occur under a more flexible policy regime.
} 
about the need to participate in any voluntary steps to reduce watering might not yet have been noteworthy. ${ }^{23}$

Mandatory watering restrictions had a similar impact across four of the five municipalities, resulting in an 11.5 percent reduction in water use (see column (2), Table 5). The marginal effects for mandatory watering restrictions are at least double those for voluntary restrictions in three municipalities (Hendersonville, High Point, and Charlotte), and are significantly different from voluntary policies at the one-percent level for these three municipalities. Mandatory restrictions are also estimated to result in a slightly larger response than voluntary restrictions in Chapel Hill (-12.7\%), although the difference between the two policies is not statistically different. We note that the household response to mandatory policies in Charlotte is similar to Hendersonville, High Point, and Chapel Hill. This similarity supports the notion that the perverse response to voluntary restrictions in Charlotte is an artifact of the timing and short duration of its voluntary policy rather than a fundamental behavioral response to voluntary restrictions by households in this municipality.

Finally, the marginal effect of mandatory policies on water use in Fayetteville (-1.5\%) is small and only significant at the $10 \%$ level. This is likely due to the fact that Fayetteville had a continuous mandatory policy in place from April $1^{\text {st }}$ through

\footnotetext{
${ }^{23}$ While we might expect no effect of a voluntary watering restriction in this context, a positive and statistically significant marginal effect is still counterintuitive. Possible reasons for a positive coefficient center on households with irrigation systems. The model indicates no response to the voluntary policy if Charlotte households with irrigation systems are dropped (coef. $=0.004$, std. error $=0.017$ ). Households with irrigation systems would appear to increase their usage during the three months the voluntary policy was in place if either moisture sensors on the systems increased irrigation intensity and there was no response by households to offset the automatic system, or households altered their irrigation settings to allow for prolonged periods of watering prior to mandatory restrictions being enacted. Another possibility is that households increased watering intensity in response to the water utility publicizing that mandatory restrictions could be forthcoming if water consumption was not decreased (e.g., Charlotte-Mecklenberg Utility, 2007). Here again, if households anticipated future mandatory restrictions, they may alter irrigation systems to water more intensely and preserve lawn heath while there was no penalty for violation.
} 
September $30^{\text {th }}$ each year since 2002. Our model identifies the average water use in months with mandatory restrictions (April through September) relative to the average monthly consumption in months without restrictions, which for this municipality are the months of October through March when outdoor watering needs are minimal. As such, it is not surprising that there is not a significant reduction in use in months with mandatory restrictions relative to this baseline for this municipality.

Heterogeneity with regards to household characteristics is presented in the last three columns of Table 5. Column (3) excludes consumptive heterogeneity, while columns (4) and (5) include interaction terms with whether a household was below the $20^{\text {th }}$ or above the $80^{\text {th }}$ percentile of water consumption for their municipality prior to implementation of watering restrictions (see Table 4 for variable definitions). Because of the correlation between having an irrigation system and being in the upper $80^{\text {th }}$ percentile of consumption, we present a model in column (5) that excludes the dummy variable for irrigation system while including consumption heterogeneity. We also exclude whether or not the household is on a larger lot in column (5), although there is little correlation between lot size and being in the upper $80^{\text {th }}$ percentile of consumption in the data. ${ }^{24}$

Results indicate that there is important heterogeneity in the responsiveness of households to prices. Columns (3) and (4) indicate that households in higher income brackets $(>\$ 75,000$ per year) and households with irrigation systems are substantially less price-elastic. Higher income households display a price elasticity that is one-third the magnitude (in absolute value) than households with income less than $\$ 75,000$ per year (-

\footnotetext{
${ }^{24}$ Fifty-six percent of households with an irrigation system are also in the $80^{\text {th }}$ percentile of consumption, while only 21 and 19 percent of households on a medium lot or a large lot, respectively, are in the $80^{\text {th }}$ percentile of consumption.
} 
0.235 as compared to -0.763 , respectively). Relative to the baseline marginal effect, the additional effect of an irrigation system reduces the price elasticity to zero.

The coefficient for the interaction between lot sizes and price presented in Columns (3) and (4) are not statistically significant. Although lot size is often used as a proxy for preference for outdoor water use (Baerenklau et al., 2014, Renwick and Green, 2000; and Mansur and Olmstead, 2012), our results suggest that irrigation systems and historical consumption patterns capture a more explicit correlation between water use and sensitivity to price.

Finally, columns (4) and (5) indicate that households in the lowest consumptive percentile $\left(<20^{\text {th }}\right.$ percentile) are least price elastic. Column (4) indicates that households in the highest consumptive group $\left(>80^{\text {th }}\right.$ percentile) are somewhat more price elastic than those in the middle $60^{\text {th }}$ percentile (the category left out of the model), although this result is small and not robust to the exclusion of other household characteristics. Lower price sensitivity among households with the most modest consumption (the lowest $20^{\text {th }}$ percentile) is not surprising given their consumption likely reflects only necessary use. Given we only observe prices trending upwards, and if we assume low-use households simply cannot make further substantive reductions in water use, we would expect our models to indicate lower price sensitivity for this group. Similarly, households in the highest consumptive group are almost assuredly using the marginal unit of water in landscapes and other outdoor uses for which more discretion is available for adjusting consumption in response to higher prices.

Interestingly, both Klaiber et al. (2014) and Baerenklau et al. (2014) find an opposite relationship between consumptive levels and price elasticities, both finding that the 
lowest consumptive levels are the most price sensitive. A potential reason for the divergence in our results is that our price-elasticity identification is based on withinhousehold variation in prices while simultaneously controlling for the effect of household-level income on consumption. Klaiber et al. (2014) do not have householdlevel data. Their unit of observation is from aggregate census block-group data. Although Baerenklau et al. (2014) utilize household consumption data, they match these households to census tract-level income measures. Census tracts typically include approximately 5,000 households and thus are not likely to adequately capture income effects necessary to isolate price sensitivity of modest water consumers separate from lower-income levels that might also result in lower consumption.

The municipal-specific effects for voluntary and mandatory policies are invariant to the inclusion of household characteristics, and remain nearly identical across models (see Panel B). Panel C presents the coefficient estimates for household characteristics interacted with voluntary and mandatory policies. As compared to heterogeneity in price responsiveness, it is striking how little heterogeneity there is in response to voluntary or mandatory watering restrictions. As indicated in columns (3) through (5), it is only households in the highest consumptive percentile $\left(>80^{\text {th }}\right.$ percentile) that exhibit any statistically significant differential response to voluntary policies. Households in the $80^{\text {th }}$ percentile of the consumption distribution on average reduce consumption by an additional five to six percentage points during periods of voluntary restrictions.

Interestingly, we see that during periods when mandatory policies are in place, households with irrigation systems are substantially more responsive than households without irrigation systems, more than doubling the average response to mandatory 
policies. This finding is notable when compared the degree to which households with irrigation systems were much less responsive to changes in price. With regards to consumptive heterogeneity, households that are in the highest consumptive group $\left(>80^{\text {th }}\right.$ percentile consumption) reduce their consumption an additional 10 to 11 percent. Columns (4) and (5) also indicate that households in the lowest consumptive group are less responsive to mandatory policies as compared to households in the middle of the consumption distribution.

\subsection{Sensitivity analysis and robustness checks}

To examine the robustness of our results, we first present models that consider alternative definitions of household characteristics. Columns (1) and (2) of Table 6 replace the dummy variable for households with income greater than $\$ 75,000$ with a series of dummy variables that indicate the income quartile in which the household falls. The dummy variable indicating that a household is in the lowest quartile $\{\leq \$ 55,000\}$ is the category left out of the model, and the variables Inc Q2, Inc Q3, and Inc Q4 indicate a household is in the second, third, or fourth (top) income quartile - representing the ranges $\{>\$ 55,000$ and $\leq \$ 95,000\},\{>\$ 95,000$ and $\leq \$ 150,000\}$, and $\{>\$ 150,000\}$, respectively.

All other covariates are exactly the same as for the models presented in columns (3) and (4) in Table 5. Municipal-specific interaction terms with the dummy variables indicating whether or not a voluntary or mandatory policy (Table 5, Panel B) are not reported in Table 6 for succinctness. Results for these variables are stable and consistent with those reported in Table 5. 
As indicated in the first two columns of Table 6, all included income quartiles are positive and significant, though the highest quartile exhibits the least degree of price sensitivity. Results also continue to suggest that there is not an economically relevant difference among households with differing incomes in responses to voluntary or mandatory policies, though the second quartile of income is marginally significant for voluntary policies. Although not reported, also estimated are models that replace income quartiles with terciles (the three categories are $\leq \$ 65,000 ;>\$ 65,000$ and $\leq \$ 112,500$; $>\$ 112,500)$ and these models continue to suggest a similar result: it is the households in the highest brackets of income that are least price responsive, and there is no qualitative difference in response to voluntary or mandatory policies among income groups.

Columns (3) and (4) explore an alternative way to characterize lot-size heterogeneity by creating a dummy variable indicating whether or not a lot is larger than three-quarters of an acre (Lot $>3 / 4$ acre). Under this definition, there is no significant heterogeneity in the responsiveness of households on the largest lots (Lot $>3 / 4$ acre) to price, indicating that the categorization of what constitutes a large lot does not affect the lack of heterogeneous responses to price. However, the models in columns (3) and (4) now indicate that households on the largest lots are somewhat more responsive to voluntary policies and relatively less responsive to mandatory policies. While the estimated effects are economically small, they are not irrelevant as they suggest that it is only households on very large lots that exhibit policy responsiveness.

Column (5) in Table 6 explores how households are characterized in terms of their historic water consumption by narrowing the definition of "high" and "low" users. The model presented in column (5) includes dummy variables that indicate whether a 
household is above the $90^{\text {th }}$ percentile in consumption prior to any policy beginning $\left(>90^{\text {th }}\right.$ cons $)$ or below the $10^{\text {th }}$ percentile $\left(<10^{\text {th }}\right.$ cons $)$. Results continue to suggest households that are the largest consumers of water on average prior to any policy implementation are more responsive to price, voluntary policies, and mandatory policies. The magnitude of these effects are larger as compared to the analogous results in Table 5. Coefficient estimates also indicate that households in the lowest $10^{\text {th }}$ percentile of consumption are less responsive to price, not different in their response to voluntary policies, and more responsive to mandatory policies and the magnitude of these results are similar to those in Table 5. Lastly, we note that narrowing the definition of "high users" to just those households in the top $90^{\text {th }}$ percentile of consumption results in a price elasticity estimate for households with an irrigation that is positive and statistically significant.

\section{Conclusions}

In this research, we employ panel data on household-level water use to explore responses to both pricing and prescriptive policies that are employed by utilities to manage demand in times of scarcity. Monthly water consumption is observed over twoand-a-half years for 1,727 households in six municipalities geographically dispersed across North Carolina. Both voluntary and mandatory water use restrictions are employed at various times by the municipalities in our sample, and water rates vary across municipalities and within municipalities over time. This rich panel data allows us to improve upon the econometric strategies of recent research that uses aggregate data (Renwick and Green, 2000; Klaiber et al., 2014; Halich and Stephenson, 2009), limited 
panel data (Olmstead, 2009; Mansur and Olmstead, 2012), or is unable to explore both pricing and prescriptive policies within the same framework (Nataraj and Hanemann, 2011; Ferraro and Price, 2013; Castledine et al., 2014; and Wichman, 2014). Our policy conclusions are identified by observed short-run, within-household decisions over water use in response to both price changes and prescriptive policies implemented during drought periods, while controlling for unobserved household characteristics in a fixedeffects framework.

Overall, we find that mandatory restrictions are effective demand management tools, reducing household consumption by an average of ten to 13 percent across the municipalities that employ these restrictions on a temporary basis. Voluntary restrictions are observed to be less effective than mandatory restrictions, reducing consumption by approximately three percent, although this result varies across municipalities. We extend our understanding of how households respond to these prescriptive policies by exploring the heterogeneity in household responses to both price and prescriptive policies with respect to income levels, lot sizes, historical consumption levels, and the presence of irrigation systems. Of note are the results concerning household income and responses to both price and prescriptive mechanisms. Our results corroborate the findings of previous research that higher income households are less sensitive to changes in price (e.g., Mansur and Olmstead, 2012; Renwick and Archibald, 1998). However, we find no evidence of heterogeneous responsiveness to non-price policies among income classes. Taken as a whole, the results imply that the incidence of pricing policies will fall more heavily on poorer households, while both voluntary and mandatory drought restrictions are relatively equitable across income groups. 
Perhaps our most striking result arises from households that have in-ground irrigation systems. We find that households with irrigation systems are virtually unresponsive to changes in price. This result can be explained by the fact that the decision to turn on an automatic irrigation system is made on an extensive margin, and so small fluctuations in price are not likely to affect month-to-month changes in irrigation intensity. Additionally, we find that households with irrigation systems do not respond to voluntary water restrictions. However, they exhibit more than double the response to mandatory watering restrictions as compared to households without irrigation systems, reducing total consumption by 20 percent or more.

Understanding how "high use" households respond to watering restrictions is also of particular interest. In addition to reducing average use, utilities are interested in reducing use by those in the upper-tail of the distribution to help avoid over-capitalization of the water delivery infrastructure. As theory predicts, water customers with high historical usage tend to be slightly more sensitive to price than the average household, whereas historically low users are less price sensitive. This result mirrors the motivation for the adoption of increasing block rate pricing structures on the merits of maintaining affordability for low use households and incentivizing conservation among high use households. Additionally, high use households are shown to exhibit a response to mandatory restrictions on the same magnitude as households with irrigation systems, decreasing total usage by approximately twenty percent. However, unlike households with irrigation systems, those with the high historic consumption are also more responsive to voluntary policies than more moderate consumption households, reducing consumption by a total of eight percent. 
To put responsiveness to prescriptive policies into monetary terms, for comparison, we compute the equivalent price increase necessary to achieve the same reduction in water use for both voluntary and mandatory policies. A voluntary policy that reduced average consumption by three percent within our study reflects a price increase of $\$ 1.08$ relative to a $\$ 10$ average price per thousand gallons. ${ }^{25}$ This increase corresponds to a 7.5 percent increase in the average consumer's monthly bill. For mandatory policies resulting in a nine percent average reduction in quantity consumed, a $\$ 3.25$ increase in average price per thousand gallons is necessary to achieve the same reduction. This price increase represents a substantial 20.6 percent increase in the average monthly bill, and if applied evenly it would imply a \$3.7 million increase in aggregate monthly expenditures on water for the estimated 250,000 residential customers served by the six utilities in our sample. $^{26}$

While efficient water pricing is preferred on welfare grounds by economists, and the regressive incidence of price policies can largely be addressed through non-uniform increases across consumption blocks (Olmstead and Stavins, 2009, Mansur and Olmstead. 2011, and Baerenklau et al. 2014), price increases of the magnitude suggested above to achieve substantial short-run reductions in water consumption are unrealistic policy choices for most U.S. municipalities. Further, our results imply that price increases are likely to be ineffectual at reducing outdoor irrigation among households

\footnotetext{
${ }^{25}$ The change in price is calculated using the formula: $\Delta P=\left(\bar{P} / \varepsilon_{P}\right)(\Delta Q / \bar{Q})$ where $\bar{P}$ is the average price in the sample, $\varepsilon_{P}$ is the estimated price elasticity, $\Delta Q$ is the change in quantity demanded induced by the policy, and $\bar{Q}$ is the sample average water use (all averages used can be obtained from summary statistics in Table 1 and estimation results from Table 5, Model 1).

${ }^{26}$ There are 374,216 total customer accounts in the municipalities in our study according to 2008 rate summary tables compiled by the Environmental Finance Center at the University of North Carolina at Chapel Hill (found here: $\underline{\mathrm{http}}$ ://www.efc.sog.unc.edu/reslib/item/tables-water-and-wastewater-rates-andrate-structures-north-carolina-january-2008. Last Accessed: July 15, 2014). Assuming, conservatively, that one-third of these accounts are non-residential, we multiply the policy-equivalent increase in customer bills by the assumed number of residential customers $(249,477)$ for both voluntary and mandatory policies.
} 
with irrigation systems. As an alternative to prices, mandatory restrictions on outdoor use are shown to be effective conservation tools that achieve uniform responses across income classes while simultaneously achieving significant consumption reductions of approximately twenty percent among households with high historical consumption or with in-ground irrigation systems. Although we do not directly consider the relative efficiency properties of prices and prescriptive policies in this research, our results suggest that non-price policies may have palatable distributional features that align with intended policy goals. This result, combined with political concerns, suggests that carefully constructed mandatory restrictions can be an important component of the policy-maker's tool kit. If efficient pricing of water is to gain public support, it is important for utility managers, policymakers, and researchers to examine and promote pricing structures that balance the competing objectives of incentivizing conservation, maintaining revenue stability, and remaining equitable. 


\section{References}

Alberini, Anna, Will Gans, and Charles Towe, 2013. "Free riding, upsizing, and energy efficiency incentives in Maryland homes." Fondazione Eni Enrico Mattei Working Paper.

Alcott, Hunt, 2011. "Social norms and energy conservation." Journal of Public Economics, Vol. 95(9-10), pp. 1082-1095.

Baerenklau, Kenneth A., Kurt A. Schwabe, and Ariel Dinar, 2014. "The residential water demand effect of increasing block rate water budgets." Land Economics, Vol. 90(4), pp. 683-699.

Bennear, Lori, Jonathan Lee and Laura O. Taylor, 2013. "Municipal Rebate Programs for Environmental Retrofits: An Evaluation of Additionality and Cost-Effectiveness." Journal of Policy Analysis and Management, Vol. 32(2), pp. 350-372.

Castledine, A., K. Moeltner, M. K. Price, S. Stoddard, 2014. "Free to choose: Promoting conservation by relaxing outdoor watering restrictions." Journal of Economic Behavior and Organization, in press.

Coleman, Eric A., 2009. "A comparison of demand-side water management strategies using disaggregate data." Public Works Management \& Policy, Vol. 13, No. 3, pp. 215223.

Corral, Leonardo, Anthony C. Fisher, and Nile W. Hatch, 1998. "Price and Non-price influences on water conservation: An econometric model of aggregate demand under nonlinear budget constraint." Agricultural Economics Association Annual Meeting, Salt Lake City, June 1998.

Charlotte-Mecklenburg Utility. 2007. "Conserve water now to avoid mandatory restrictions later," Charlotte News and Observer, June 1, 2007, pg 10A, accessible at http://cmudata.com/newsstoryarchive.cfm, Last Accessed: August, 27, 2014.

Dalhuisen, J., Florax, R., de Groot, H. and Nijkamp, P., 2003. "Price and income elasticities of residential water demand: A meta-analysis." Land Economics, Vol. 79(2), pp. 292-308.

Espey, M., J. Espey, and W.D. Shaw, (1997). "Price elasticity of residential demand for water: A meta-analysis.” Water Resources Research, 33(6), pp. 1369-1374.

Ferraro, Paul J., Juan Jose Miranda, and Michael K. Price, (2011). "The Persistence of Treatment Effects with Norm-Based Policy Instruments: Evidence from a Randomized Environmental Policy Experiment." American Economic Review: Papers and Proceedings, 101(3), pp. 318-322. 
Ferraro, Paul J. and Michael K. Price, 2013. "Using non-pecuniary strategies to influence behavior: Evidence from a large-scale field experiment." The Review of Economics and Statistics, Vol. 95, No. 1, pp. 64-73.

Ferraro, Paul J. and Juan Jose Miranda, 2014. "Can panel data designs and estimators substitute for randomized controlled trials in the evaluation of social programs?" Working Paper.

Ferraro, Paul J. and Casey J. Wichman, 2014. "A design replication study with panel data and two control groups." Working Paper.

Halich, Greg, and Kurt Stephenson, 2009. "Residential water-use restrictions and municipal effort." Land Economics, Vol. 84, No. 4, pp. 614-626.

Harding, Matthew and Carlos Lamarche, 2009. "A quantile regression approach for estimating panel data models using instrumental variables." Economic Letters, Vol. 104, pp. 133-135.

Ito, Koichiro, 2014. "Do consumers respond to marginal or average price: Evidence from nonlinear electricity pricing." The American Economic Review, Vol 104, No. 2, pp. 537563.

Klaiber, H. Allen, V. Kerry Smith, Michael Kaminsky, and Aaron Strong, 2014. "Measuring price elasticities for residential water demand with limited information." Land Economics, Vol. 90, No. 1, pp. 100-113.

Kleibergen, F. and Paap, R. 2006. Generalized Reduced Rank Tests Using the Singular Value Decomposition. Journal of Econometrics, Vol. 133, pp. 97-126.

Kenny, J.F., Barber, N.L., Hutson, S.S., Linsey, K.S., Lovelace, J.K., and Maupin, M.A., 2009, Estimated use of water in the United States in 2005: U.S. Geological Survey Circular 1344, 52 pp, available at http://pubs.usgs.gov/circ/1344/, last accessed February 23, 2012.

Mansur, Erin T. \& Olmstead, Sheila M., 2012. "The value of scarce water: Measuring the inefficiency of municipal regulations." Journal of Urban Economics, Vol. 71(3), pp. 332346.

Michelsen, Ari M., J. Thomas McGuckin, and Donna Stumpf, 1999. " Nonprice water conservation programs as a demand management tool." Journal of the American Water Resources Association, Vol. 35, No. 3, pp. 593-602.

Nataraj, Shanthi and W. Michael Hanemann, 2011. "Does marginal price matter? A regression discontinuity approach to estimating water demand." Journal of Environmental Economics and Management, Vol. 61, pp. 198-212. 
Nieswiadomy, Michael L. and David J. Molina, 1989. “Comparing Residential Water Demand Estimates under Decreasing and Increasing Block Rates Using Household Level Data." Land Economics, Vol. 65(3), pp. 280-289.

Olmstead, Shelia M., 2009. "Reduced-form versus structural models of water demand under nonlinear prices." Journal of Business \& Economics and Statistics, Vol. 27, No 1, pp. 84-94.

Olmstead, Sheila, M., W. Michael Hanemann, and Robert N. Stavins, 2007. "Water demand under alternative price structures." Journal of Environmental Economics and Management, Vol. 54, pp. 181-198.

Olmstead, Sheila M. and Robert N. Stavins, 2009. "Comparing price and nonprice approaches to urban water conservation." Water Resources Research, Vol. 45.

Renwick, Mary E. and Sandra O. Archibald, 1998. "Demand side management policies for residential water use: Who bears the conservation burden?" Land Economics, Vol. 47(3), pp. 343-359.

Renwick, Mary E. and Green, Richard D., 2000. "Do Residential Water Demand Side Management Policies Measure Up? An Analysis of Eight California Water Agencies." Journal of Environmental Economics and Management Vol. 40, pp. 37-55.

Schaffer, Mark E., 2005. "XTIVREG2: Stata module to perform extended IV/2SLS, GMM and AC/HAC, LIML and k-class regression for panel data models," Statistical Software Components, S456501, Boston College Department of Economics, revised 24 Jul 2012.

U.S. Environmental Protection Agency, 2009. "Water on tap: What you need to know." Environmental Protection Agency, December, 2009.

Wichman, Casey J., 2011. "Who responds to non-price policies? A reduced form analysis of residential water demand." Master's thesis, North Carolina State University.

Wichman, Casey J., 2014. "Perceived price in residential water demand: Evidence from a natural experiment," Journal of Economic Behavior and Organization, in press. 
Table 1. Summary Statistics.

\begin{tabular}{lccccccc}
\hline & $\begin{array}{c}\text { Chapel } \\
\text { Hill }\end{array}$ & Charlotte & $\begin{array}{c}\text { Fayette- } \\
\text { Ville }\end{array}$ & $\begin{array}{c}\text { Green- } \\
\text { Ville }\end{array}$ & $\begin{array}{c}\text { Hender- } \\
\text { Sonville }\end{array}$ & $\begin{array}{c}\text { High } \\
\text { Point }\end{array}$ & Total \\
\hline Households (N) & 234 & 363 & 388 & 226 & 245 & 271 & 1,727 \\
\cline { 2 - 8 } Panel A: & \multicolumn{7}{c}{ Demographic Characteristics } \\
Mean HH Income & 183,987 & 135,520 & 88,622 & 107,931 & 124,692 & 114,697 & 123,034 \\
(std. dev.) & $(115,693)$ & $(97,469)$ & $(56,627)$ & $(66,176)$ & $(88,834)$ & $(59,002)$ & $(87,140)$ \\
[Median] & {$[162,500]$} & {$[112,500]$} & {$[85,000]$} & {$[112,500]$} & {$[112,500]$} & {$[112,500]$} & {$[112,500]$} \\
Mean Home Value & 355,203 & 244,868 & 141,645 & 188,328 & 290,638 & 188,220 & 226,214 \\
(std. dev.) & $(133,218)$ & $(124,512)$ & $(54,530)$ & $(79,609)$ & $(142,735)$ & $(70,960)$ & $(124,512)$ \\
[Median] & {$[325,000]$} & {$[225,000]$} & {$[137,500]$} & {$[187,500]$} & {$[275,000]$} & {$[187,500]$} & {$[187,500]$} \\
Mean Lot Acreage & 0.553 & 0.532 & 0.633 & 0.526 & 1.122 & 0.513 & 0.634 \\
(std. dev.) & $(0.676)$ & $(1.378)$ & $(1.614)$ & $(0.607)$ & $(3.008)$ & $(1.020)$ & $(1.603)$ \\
[Median] & {$[0.420]$} & {$[0.295]$} & {$[0.420]$} & {$[0.420]$} & {$[0.630]$} & {$[0.420]$} & {$[0.420]$} \\
Mean Home sqft. & 2,725 & 2,711 & 2,790 & 2,633 & 2,793 & 2,636 & 2,718 \\
(std. dev.) & $(808.1)$ & $(939.2)$ & $(1188.5)$ & $(980.0)$ & $(1085.6)$ & $(908.9)$ & $(1003.7)$ \\
[Median] & {$[2,750]$} & {$[2,250]$} & {$[2,250]$} & {$[2,250]$} & {$[2,250]$} & {$[2,250]$} & {$[2,250]$} \\
Mean HH Size & 2.858 & 2.573 & 2.473 & 2.378 & 2.335 & 2.618 & 2.540 \\
(std. dev.) & $(1.314)$ & $(1.183)$ & $(1.217)$ & $(1.086)$ & $(1.041)$ & $(1.231)$ & $(1.198)$ \\
[Median] & {$[2.0]$} & {$[2.0]$} & {$[2.0]$} & {$[2.0]$} & {$[2.0]$} & {$[2.0]$} & {$[2.0]$} \\
& & & & & & &
\end{tabular}

Panel B:

Monthly Household Water Consumption: 30 Month Average (1,000 gallons)

Mean

(std. dev.)

[Median]

$\left[10^{\text {th }}-90^{\text {th }}\right.$

Percentile]

\begin{tabular}{ccccccc}
\hline 5.232 & 6.235 & 5.099 & 5.560 & 4.717 & 4.668 & 5.289 \\
$(3.825)$ & $(4.795)$ & $(3.649)$ & $(4.104)$ & $(3.649)$ & $(3.031)$ & $(3.947)$ \\
{$[4.000]$} & {$[5.236]$} & {$[4.000]$} & {$[4.480]$} & {$[3.800]$} & {$[3.740]$} & {$[4.480]$} \\
{$[2.0-9.0]$} & {$[2.2-11.2]$} & {$[2.0-9.0]$} & {$[2.2-9.7]$} & {$[1.9-8.5]$} & {$[1.5-8.2]$} & {$[2.0-9.0]$}
\end{tabular}

Panel C:

Monthly Average Effective Water Charges by Municipality

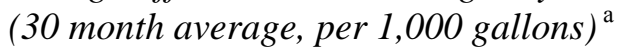

\begin{tabular}{lccccccc}
\cline { 2 - 7 } Mean AP & 12.44 & 6.78 & 8.79 & 9.10 & 13.06 & 11.90 & 10.00 \\
Mean MP & 8.95 & 7.02 & 7.62 & 6.70 & 10.03 & 8.23 & 7.99 \\
Mean Base Charge & 17.95 & 3.49 & 7.70 & 12.59 & 13.39 & 15.26 & 10.90 \\
\hline
\end{tabular}

${ }^{a}$ Effective prices are calculated as monthly prices paid by consumers adjusted for inflation. 
Table 2. Drought conditions and policy responses by municipality. ${ }^{\mathrm{a}}$

\begin{tabular}{|c|c|c|c|c|c|c|c|}
\hline & & Chapel Hill & Charlotte & Fayetteville & Greenville & $\begin{array}{l}\text { Henderson- } \\
\text { ville }\end{array}$ & High Point \\
\hline \multirow{6}{*}{2006} & $\overline{\mathrm{Jul}}$ & & & $\overline{\mathbf{M}}$ & & & \\
\hline & Aug & & & M & & & \\
\hline & Sep & & & M & & & \\
\hline & Oct & & & & & & \\
\hline & Nov & & & & & & \\
\hline & Dec & & & & & & \\
\hline \multirow{12}{*}{2007} & Jan & & & & & & \\
\hline & Feb & & & & & & \\
\hline & Mar & & & & & & \\
\hline & Apr & & & & & & \\
\hline & May & & & M & & & \\
\hline & Jun & & V & M & & & \\
\hline & Jul & & V & M & & & \\
\hline & Aug & & V & $\ddot{\mathrm{M}}$ & & & \\
\hline & Sep & & i: & ì & & 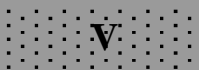 & $\mathrm{V}$ \\
\hline & Oct & $\mathrm{v}$ & $\mathrm{i}$ & $\mathrm{M}$ & & $\mathrm{V}$ & $\mathrm{M}$ \\
\hline & Nov & M & $\mathrm{M}$ & 4 & & $\mathscr{H}$ & $y$ \\
\hline & Dec & 814 & 24 & $\mathbb{4}$ & $\mathscr{W}$ & $\mathbb{Z}$ & $\mathbb{W}$ \\
\hline \multirow{12}{*}{2008} & Jan & M & 64 & 61 & $\mathscr{W}$ & 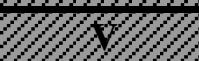 & $\mathbb{1}$ \\
\hline & Feb & i & $\mathbb{K}$ & M: & $\mathrm{v}:$ & $\mathbb{E}$ & $\mathbb{E}$ \\
\hline & Mar & M & $\mathrm{M}:$ & M & V & $\mathrm{V}$ & \\
\hline & Apr & V & M & $\mathbf{M}$ & V & V & \\
\hline & May & V & M & M & V & V & \\
\hline & Jun & & M & $\ddot{\mathrm{M}}$ & & $\mathrm{V}$ & \\
\hline & Jul & & $\mathbf{M}$ & $\mathscr{1}$ & & $\mathrm{V}$ & \\
\hline & Aug & & $\mathbf{M}$ & Mi: & & i & \\
\hline & Sep & & M & $\mathrm{M}$ & & M & \\
\hline & Oct & & M & ì: & & V & \\
\hline & Nov & & M & $\mathrm{M}$ & & V & \\
\hline & Dec & & M & $\mathrm{M}$ & & V & \\
\hline
\end{tabular}

${ }^{\mathrm{a}}$ Drought conditions are reported weekly using a scale in which 0 equals normal conditions and 5 equals exceptional drought (see Section 2.3 for a detailed description). Average conditions over the month are represented by shades of gray in which the darkest shade with diagonal lines indicates a month in which all weeks were classified as having "exceptional drought," and no color indicates a month in which the average drought condition across weeks in that month is less than 1.0. The lightest gray indicates an average of 1 to 1.99 , and each successively darker shade of gray indicates monthly averages that range from 2 to $2.99,3$ to 3.99 , and (with dots), 4 to 4.99 . If a voluntary or mandatory watering restriction was in place for at least half the month, the cell is labeled with a $\mathrm{V}$ or $\mathrm{M}$, respectively. 
Table 3. Components of Voluntary and Mandatory Restrictions Implemented. ${ }^{\text {a }}$

\begin{tabular}{|c|c|c|c|c|c|}
\hline & \multicolumn{2}{|c|}{ Voluntary Restrictions } & \multicolumn{3}{|c|}{ Mandatory Restrictions } \\
\hline & $\begin{array}{c}\text { Turf } \\
\text { irrigation }\end{array}$ & $\begin{array}{c}\text { Other } \\
\text { outdoor use }\end{array}$ & Turf irrigation & $\begin{array}{l}\text { Non-turf } \\
\text { irrigation }\end{array}$ & $\begin{array}{c}\text { Other } \\
\text { outdoor use }\end{array}$ \\
\hline Chapel Hill (CH) & Odd-even & Limited & $\mathrm{X}$ & Limited $^{\mathrm{b}}$ & $\mathrm{X}$ \\
\hline $\begin{array}{l}\text { Henderson- } \\
\text { ville (HV) }\end{array}$ & Limited & Limited & $\mathrm{X}$ & $X^{c}$ & $\mathrm{X}$ \\
\hline Greenville (GV) & Limited & $\mathrm{X}$ & & & \\
\hline High Point (HP) & Odd-even & $\mathrm{X}$ & $\mathrm{X}$ & $X^{c}$ & $\mathrm{X}$ \\
\hline Fayetteville (FV) & & & Odd-even & & $X^{d}$ \\
\hline Charlotte (CLT) & Limited & & $\begin{array}{c}\text { X: Sep07-Mar08 } \\
\text { Limited: } \\
\text { Apr-Sep08 } \\
\text { Odd-even: } \\
\text { Sep-Dec08 }\end{array}$ & & $\begin{array}{c}\text { X: Sep07- } \\
\text { Apr08 } \\
\text { Limited: } \\
\text { May-Dec08 }\end{array}$ \\
\hline
\end{tabular}

\footnotetext{
${ }^{a} \mathrm{An}$ " $\mathrm{X}$ " indicates a complete restriction (ban) is suggested during voluntary restrictions or required during mandatory restrictions. "Odd-even" denotes an alternating watering schedule based on household's street address and "Limited" denotes that there are time-of-day or other miscellaneous water-use restrictions.

${ }^{\mathrm{b}}$ Non-turf irrigation was completely prohibited in the last month in which mandatory restrictions were in place.

${ }^{\mathrm{c}}$ Limited watering of vegetable gardens only are allowed.

${ }^{\mathrm{d}}$ Complete restriction on other outdoor uses added to mandatory restrictions in November 2007.
} 
Table 4. Variable definitions and summary statistics.

\begin{tabular}{|c|c|c|}
\hline Variable Name & Definition & $\begin{array}{l}\text { Mean (std. dev.) } \\
\{\mathrm{N}=48,166\}\end{array}$ \\
\hline \multicolumn{3}{|c|}{ Panel A: Consumption and Fees } \\
\hline$q_{i k t}$ & $\begin{array}{l}\text { Monthly water consumption for household } i \text { in municipality } k \text { in } \\
\text { month } t(1,000 \text { gallons). }\end{array}$ & $\begin{array}{c}5.29 \\
(3.95)\end{array}$ \\
\hline$A P_{i k t}$ & $\begin{array}{l}\text { Average price per } 1,000 \text { gallons consumed by household } i \text { in } \\
\text { municipality } k \text { in month } t \text {, computed as total service fee divided } \\
\text { by quantity of water consumed during the billing cycle. }\end{array}$ & $\begin{array}{l}\$ 10.00 \\
(3.24)\end{array}$ \\
\hline$M P_{k t}^{j}$ & $\begin{array}{l}\text { Marginal price per } 1,000 \text { gallons in price block } j \text { in municipality } \\
k \text { in month } t \text {. }\end{array}$ & $\begin{array}{l}\$ 7.99 \\
(1.55)\end{array}$ \\
\hline Base $_{k t}$ & $\begin{array}{l}\text { Base service fee for water and sewer use charged in municipality } \\
k \text { in month } t \text {. }\end{array}$ & $\begin{array}{l}\$ 11.25 \\
(5.25)\end{array}$ \\
\hline \multicolumn{3}{|c|}{ Panel B: Policy and Weather } \\
\hline Voluntary $_{k t}$ & $\begin{array}{l}=1 \text { if a voluntary water restriction was in place for any part of a } \\
\text { month; }=0 \text { otherwise. }\end{array}$ & $\begin{array}{c}0.15 \\
(0.36)\end{array}$ \\
\hline Mandatory $_{k t}$ & $\begin{array}{l}=1 \text { if a mandatory water restriction was in place for any part of } \\
\text { a month; }=0 \text { otherwise. }\end{array}$ & $\begin{array}{c}0.32 \\
(0.47)\end{array}$ \\
\hline $\operatorname{Rain}_{k t}$ & Monthly rainfall, in inches. ${ }^{a}$ & $\begin{array}{l}3.69 \\
(2.21)\end{array}$ \\
\hline Temp $_{k t}$ & Mean of daily mean maximum temperatures during the month. ${ }^{a}$ & $\begin{array}{l}72.28 \\
(13.07)\end{array}$ \\
\hline \multicolumn{3}{|c|}{ Panel C: Household Characteristics } \\
\hline$>75 k$ inc & $\begin{array}{l}=1 \text { if household income is greater than } \$ 75,000 \text { per year; }=0 \\
\text { otherwise. }\end{array}$ & $\begin{array}{c}0.72 \\
{[\mathrm{HH}=1,238]}\end{array}$ \\
\hline Irrsys & $\begin{array}{l}=1 \text { if household has installed an in-ground irrigation system; } \\
=0 \text { otherwise. }\end{array}$ & $\begin{array}{c}0.07 \\
{[\mathrm{HH}=127]}\end{array}$ \\
\hline Small lot & $=1$ if lot size $<=0.25$ acres; $=0$ otherwise & $\begin{array}{c}0.19 \\
{[\mathrm{HH}=323]}\end{array}$ \\
\hline Medlot & $=1$ if lot size is $>0.25$ acre but $<=0.50 ;=0$ otherwise. & $\begin{array}{c}0.39 \\
{[\mathrm{HH}=678]}\end{array}$ \\
\hline Biglot & $=1$ if lot size is greater than 0.50 acre; $=0$ otherwise. & $\begin{array}{c}0.42 \\
{[\mathrm{HH}=726]}\end{array}$ \\
\hline$>80$ th cons & $\begin{array}{l}=1 \text { if mean household consumption before non-price policies } \\
\text { were implemented (July 2006-Aug 2007) is above the } 80^{\text {th }} \\
\text { percentile; }=0 \text { otherwise. }\end{array}$ & $\begin{array}{l}0.20 \\
{[\mathrm{HH}=343]}\end{array}$ \\
\hline$<20$ th cons & $\begin{array}{l}=1 \text { if mean household consumption before non-price policies } \\
\text { were implemented (July 2006-Aug 2007) is below the } 20^{\text {th }} \\
\text { percentile; }=0 \text { otherwise. }\end{array}$ & $\begin{array}{c}0.20 \\
{[\mathrm{HH}=353]}\end{array}$ \\
\hline
\end{tabular}

${ }^{a}$ Monthly rainfall and mean maximum temperature measurements were obtained from the N.C. State Climate office and is measured at a representative weather station for each municipality.

${ }^{\mathrm{b}}$ The consumption range is July 2006-May 2007 for Charlotte due to the earlier adoption of voluntary restrictions. 
Table 5. Base Model Results ${ }^{\mathrm{a}}$

\begin{tabular}{|c|c|c|c|c|c|c|}
\hline \multirow[b]{2}{*}{ Variable } & \multicolumn{6}{|c|}{ Coefficient (Std. Err.) } \\
\hline & & (1) & (2) & (3) & (4) & (5) \\
\hline & \multicolumn{6}{|c|}{ Panel A } \\
\hline AvgPrice & & $\begin{array}{c}-0.277^{* * *} \\
(0.045)\end{array}$ & $\begin{array}{c}-0.132 * * * \\
(0.048)\end{array}$ & $\begin{array}{c}-0.763 * * * \\
(0.140)\end{array}$ & $\begin{array}{c}-0.846^{* * *} \\
(0.139)\end{array}$ & $\begin{array}{c}-0.779 * * * \\
(0.098)\end{array}$ \\
\hline \multirow[t]{7}{*}{ AvgPrice* } & $\ldots>75 \mathrm{k}$ Inc & & & $\begin{array}{c}0.528 * * * \\
(0.103)\end{array}$ & $\begin{array}{c}0.583 * * * \\
(0.104)\end{array}$ & $\begin{array}{c}0.686 * * * \\
(0.105)\end{array}$ \\
\hline & ...Irr Sys & & & $\begin{array}{c}0.769 * * * \\
(0.194)\end{array}$ & $\begin{array}{c}0.976 * * * \\
(0.199)\end{array}$ & \\
\hline & ...Med lot & & & $\begin{array}{l}-0.014 \\
(0.127)\end{array}$ & $\begin{array}{c}0.046 \\
(0.126)\end{array}$ & \\
\hline & ...Big lot & & & $\begin{array}{c}0.167 \\
(0.130)\end{array}$ & $\begin{array}{c}0.154 \\
(0.128)\end{array}$ & \\
\hline & $\ldots>80$ th cons. & & & & $\begin{array}{c}-0.170 * \\
(0.101)\end{array}$ & $\begin{array}{c}0.048 \\
(0.101)\end{array}$ \\
\hline & $\ldots<20$ th cons. & & & & $\begin{array}{c}0.562 * * * \\
(0.133)\end{array}$ & $\begin{array}{c}0.745^{* * *} \\
(0.136)\end{array}$ \\
\hline & \multicolumn{6}{|c|}{ Panel B ${ }^{b}$} \\
\hline Voluntary & & $\begin{array}{c}-0.032 * * * \\
(0.005)\end{array}$ & $\begin{array}{c}-0.047 * * * \\
(0.010)\end{array}$ & $\begin{array}{c}-0.034^{*} \\
(0.018)\end{array}$ & $\begin{array}{l}-0.027 \\
(0.019)\end{array}$ & $\begin{array}{c}-0.033^{* *} \\
(0.014)\end{array}$ \\
\hline Voluntary* & ...Chapel Hill & & $\begin{array}{c}-0.078 * * * \\
(0.020)\end{array}$ & $\begin{array}{c}-0.085^{* * * *} \\
(0.021)\end{array}$ & $\begin{array}{c}-0.081 * * * \\
(0.021)\end{array}$ & $\begin{array}{c}-0.082 * * * \\
(0.021)\end{array}$ \\
\hline & ...Greenville & & $\begin{array}{l}-0.002 \\
(0.015)\end{array}$ & $\begin{array}{l}-0.005 \\
(0.015)\end{array}$ & $\begin{array}{l}-0.002 \\
(0.015)\end{array}$ & $\begin{array}{l}-0.001 \\
(0.015)\end{array}$ \\
\hline & ...High Point & & $\begin{array}{l}-0.005 \\
(0.014)\end{array}$ & $\begin{array}{l}-0.006 \\
(0.015)\end{array}$ & $\begin{array}{l}-0.009 \\
(0.015)\end{array}$ & $\begin{array}{l}-0.008 \\
(0.014)\end{array}$ \\
\hline & ...Charlotte & & $\begin{array}{c}0.101 * * * \\
(0.020)\end{array}$ & $\begin{array}{c}0.097 * * * \\
(0.020)\end{array}$ & $\begin{array}{c}0.101 * * * \\
(0.020)\end{array}$ & $\begin{array}{c}0.106 * * * \\
(0.020)\end{array}$ \\
\hline Mandatory & & $\begin{array}{c}-0.092 * * * \\
(0.005)\end{array}$ & $\begin{array}{c}-0.115^{* * * *} \\
(0.023)\end{array}$ & $\begin{array}{c}-0.096 * * * \\
(0.027)\end{array}$ & $\begin{array}{c}-0.102 * * * \\
(0.028)\end{array}$ & $\begin{array}{c}-0.100 * * * \\
(0.025)\end{array}$ \\
\hline Mandatory* & ...Chapel Hill & & $\begin{array}{l}-0.012 \\
(0.026)\end{array}$ & $\begin{array}{l}-0.013 \\
(0.027)\end{array}$ & $\begin{array}{l}-0.000 \\
(0.027)\end{array}$ & $\begin{array}{l}-0.008 \\
(0.027)\end{array}$ \\
\hline & ...High Point & & $\begin{array}{c}0.015 \\
(0.033)\end{array}$ & $\begin{array}{c}0.004 \\
(0.034)\end{array}$ & $\begin{array}{c}0.007 \\
(0.034)\end{array}$ & $\begin{array}{c}0.011 \\
(0.034)\end{array}$ \\
\hline & ...Fayetteville & & $\begin{array}{c}0.100 * * * \\
(0.024)\end{array}$ & $\begin{array}{c}0.105^{* * * *} \\
(0.024)\end{array}$ & $\begin{array}{c}0.098 * * * \\
(0.025)\end{array}$ & $\begin{array}{c}0.092 * * * \\
(0.024)\end{array}$ \\
\hline & ...Charlotte & & $\begin{array}{l}-0.017 \\
(0.025)\end{array}$ & $\begin{array}{l}-0.002 \\
(0.025)\end{array}$ & $\begin{array}{c}0.009 \\
(0.025)\end{array}$ & $\begin{array}{l}-0.002 \\
(0.025)\end{array}$ \\
\hline
\end{tabular}

continued, next page 
Table 5. Continued.

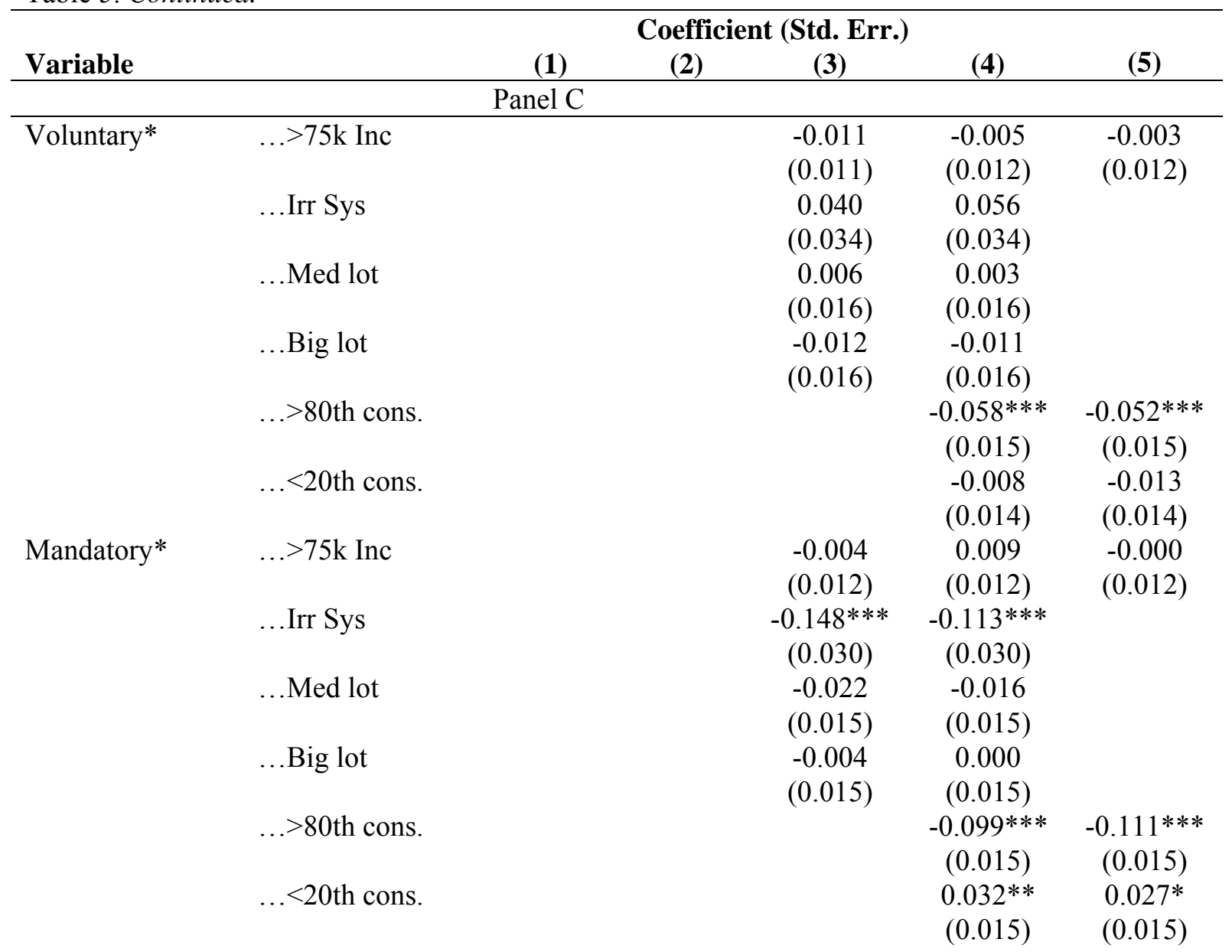

\footnotetext{
Within R-squared

$0.114 \quad 0.108$

$0.099 \quad 0.103$

0.097

${ }^{\text {a }}$ All models include 48,166 observations (1,727 households) and include weather covariates, month and household fixed effects as described for equation (1). Significance at the 10,5 and 1 percent level is indicated by $* * *$, and $* * *$, respectively. All models report standard errors that are robust to an unknown form of heteroskedasticity and clustered at the household level.

${ }^{\mathrm{b}}$ Fayetteville is not interacted with the voluntary policy dummy variable because Fayetteville had no voluntary policies during the study period. Similarly, Greenville had no mandatory policies during the study period and is thus not interacted with the mandatory policy dummy variable. Hendersonville is the left out category for both voluntary and mandatory policies.
} 
Table 6. Results Using Alternative Measures of Key Covariates ${ }^{\mathrm{a}}$

\begin{tabular}{|c|c|c|c|c|c|c|}
\hline \multirow[b]{2}{*}{ Variable } & & \multicolumn{5}{|c|}{ Coefficient (Std. Err.) } \\
\hline & & (1) & (2) & (3) & (4) & (5) \\
\hline \multicolumn{2}{|l|}{ AvgPrice } & $\begin{array}{c}-0.814 * * * \\
(0.148)\end{array}$ & $\begin{array}{c}-0.875^{* * *} \\
(0.148)\end{array}$ & $\begin{array}{c}-0.675 * * * \\
(0.097)\end{array}$ & $\begin{array}{c}-0.750 * * * \\
(0.101)\end{array}$ & $\begin{array}{c}-0.853 * * * \\
(0.135)\end{array}$ \\
\hline \multirow[t]{12}{*}{ AvgPrice* } & ...Inc Q2 & $\begin{array}{l}0.328 * * \\
(0.144)\end{array}$ & $0.369 * *$ & & & \\
\hline & ...Inc Q3 & $\begin{array}{c}0.299 * * \\
(0.131)\end{array}$ & $\begin{array}{c}0.331 * * \\
(0.130)\end{array}$ & & & \\
\hline & ...Inc Q4 & $\begin{array}{c}0.737 * * * \\
(0.126)\end{array}$ & $\begin{array}{c}0.745 * * * \\
(0.127)\end{array}$ & & & \\
\hline & $\ldots>75 \mathrm{k}$ Inc & & & $\begin{array}{c}0.517 * * * \\
(0.104)\end{array}$ & $\begin{array}{c}0.582 * * * \\
(0.105)\end{array}$ & $\begin{array}{c}0.504 * * * \\
(0.104)\end{array}$ \\
\hline & ...Irr Sys & $\begin{array}{c}0.696 * * * \\
(0.193)\end{array}$ & $\begin{array}{c}0.927 * * * \\
(0.197)\end{array}$ & $\begin{array}{c}0.746 * * * \\
(0.194)\end{array}$ & $\begin{array}{c}0.958 * * * \\
(0.199)\end{array}$ & $\begin{array}{c}1.201 * * * \\
(0.211)\end{array}$ \\
\hline & ...Med Lot & $\begin{array}{c}0.021 \\
(0.127)\end{array}$ & $\begin{array}{c}0.086 \\
(0.126)\end{array}$ & & & $\begin{array}{c}0.151 \\
(0.124)\end{array}$ \\
\hline & ...Big Lot & $\begin{array}{c}0.181 \\
(0.131)\end{array}$ & $\begin{array}{c}0.172 \\
(0.127)\end{array}$ & & & $\begin{array}{c}0.263 * * \\
(0.126)\end{array}$ \\
\hline & $\ldots$..Lot $>3 / 4$ acre & & & $\begin{array}{l}-0.019 \\
(0.119)\end{array}$ & $\begin{array}{l}-0.071 \\
(0.118)\end{array}$ & \\
\hline & $\ldots>80$ th cons & & $\begin{array}{c}-0.211 * * \\
(0.101)\end{array}$ & & $\begin{array}{l}-0.165 \\
(0.101)\end{array}$ & \\
\hline & $\ldots<20$ th cons. & & $\begin{array}{c}0.587 * * * \\
(0.133)\end{array}$ & & $\begin{array}{c}0.625 * * * \\
(0.135)\end{array}$ & \\
\hline & $\ldots>90$ th cons & & & & & $\begin{array}{c}-0.478 * * * \\
(0.148)\end{array}$ \\
\hline & $\ldots<10$ th cons & & & & & $\begin{array}{c}0.358 * * \\
(0.175)\end{array}$ \\
\hline \multirow[t]{7}{*}{ Voluntary* } & ...Inc Q2 & $\begin{array}{l}-0.027 * \\
(0.015)\end{array}$ & $\begin{array}{l}-0.028 * \\
(0.015)\end{array}$ & & & \\
\hline & ...Inc Q3 & $\begin{array}{l}-0.016 \\
(0.015)\end{array}$ & $\begin{array}{l}-0.006 \\
(0.015)\end{array}$ & & & \\
\hline & ...Inc Q4 & $\begin{array}{c}0.006 \\
(0.015)\end{array}$ & $\begin{array}{c}0.020 \\
(0.015)\end{array}$ & & & \\
\hline & $\ldots>75 \mathrm{k}$ Inc & & & $\begin{array}{l}-0.012 \\
(0.011)\end{array}$ & $\begin{array}{l}-0.007 \\
(0.012)\end{array}$ & $\begin{array}{l}-0.004 \\
(0.012)\end{array}$ \\
\hline & ...Irr Sys & $\begin{array}{c}0.034 \\
(0.034)\end{array}$ & $\begin{array}{c}0.050 \\
(0.034)\end{array}$ & $\begin{array}{c}0.040 \\
(0.034)\end{array}$ & $\begin{array}{c}0.055 \\
(0.034)\end{array}$ & $\begin{array}{c}0.052 \\
(0.035)\end{array}$ \\
\hline & ...Med Lot & $\begin{array}{c}0.004 \\
(0.016)\end{array}$ & $\begin{array}{c}0.001 \\
(0.016)\end{array}$ & & & $\begin{array}{l}-0.002 \\
(0.016)\end{array}$ \\
\hline & ...Big Lot & $\begin{array}{l}-0.012 \\
(0.016)\end{array}$ & $\begin{array}{l}-0.010 \\
(0.016)\end{array}$ & & & $\begin{array}{l}-0.015 \\
(0.016)\end{array}$ \\
\hline
\end{tabular}




\begin{tabular}{|c|c|c|c|c|c|c|}
\hline \multirow{2}{*}{ Variable } & & \multicolumn{5}{|c|}{ Coefficient (Std. Err.) } \\
\hline & & (1) & (2) & (3) & (4) & (5) \\
\hline & $\ldots$...ot $>3 / 4$ acre & & & $-0.032 * *$ & $-0.028 *$ & \\
\hline & & & & $(0.015)$ & $(0.015)$ & \\
\hline & $\ldots>80$ th cons. & & $-0.065 * * *$ & & $-0.057 * * *$ & \\
\hline & & & $(0.015)$ & & $(0.015)$ & \\
\hline & $\ldots<20$ th cons. & & -0.003 & & -0.008 & \\
\hline & & & $(0.014)$ & & $(0.014)$ & \\
\hline & $\ldots>90$ th cons. & & & & & $-0.070 * * *$ \\
\hline & 10 & & & & & $(0.022)$ \\
\hline & $\ldots<10$ th cons. & & & & & -0.002 \\
\hline & & & & & & $(0.019)$ \\
\hline \multirow[t]{23}{*}{ Mandatory* } & ...Inc Q2 & -0.003 & -0.000 & & & \\
\hline & & $(0.015)$ & $(0.015)$ & & & \\
\hline & ...Inc Q3 & 0.015 & $0.028 *$ & & & \\
\hline & & $(0.015)$ & $(0.016)$ & & & \\
\hline & ...Inc Q4 & -0.013 & 0.019 & & & \\
\hline & & $(0.016)$ & $(0.017)$ & & & \\
\hline & $\ldots>75 \mathrm{k}$ Inc & & & -0.004 & 0.008 & 0.008 \\
\hline & & & & $(0.012)$ & $(0.012)$ & $(0.012)$ \\
\hline & ...Irr Sys & $-0.149 * * *$ & $-0.119 * * *$ & $-0.146 * * *$ & $-0.111 * * *$ & $-0.095 * * *$ \\
\hline & & $(0.030)$ & $(0.030)$ & $(0.030)$ & $(0.030)$ & $(0.030)$ \\
\hline & ...Med Lot & -0.022 & -0.015 & & & -0.018 \\
\hline & & $(0.015)$ & $(0.015)$ & & & $(0.015)$ \\
\hline & ...Big Lot & -0.005 & 0.001 & & & -0.002 \\
\hline & & $(0.015)$ & $(0.015)$ & & & $(0.015)$ \\
\hline & $\ldots$...ot $>3 / 4$ acre & & & 0.021 & $0.022 *$ & \\
\hline & & & & $(0.013)$ & $(0.013)$ & \\
\hline & $\ldots>80$ th cons. & & $-0.103 * * *$ & & $-0.101 * * *$ & \\
\hline & & & $(0.015)$ & & $(0.015)$ & \\
\hline & $\ldots<20$ th cons. & & $0.037 * *$ & & $0.031 * *$ & \\
\hline & & & $(0.015)$ & & $(0.015)$ & \\
\hline & $\ldots>90$ th cons. & & & & & $-0.158 * * *$ \\
\hline & & & & & & $(0.025)$ \\
\hline & $\ldots<10$ th cons. & & & & & $\begin{array}{c}0.056^{* * *} \\
(0.019)\end{array}$ \\
\hline
\end{tabular}

\footnotetext{
$\begin{array}{llllll}\text { Within R-squared } & 0.098 & 0.098 & 0.099 & 0.096 & 0.101\end{array}$

${ }^{a}$ All models include 48,166 observations (1,727 households) and include and include weather covariates, month and household fixed effects as described for equation (1). Also included, but not reported here for succinctness, are municipal-specific interaction terms with the dummy variables indicating whether or not a voluntary or mandatory policy was in place during the month (these covariates are reported in Table 5, Panel B and change little across models in Table 5 or 6 ). Significance at the 10,5 and 1 percent level is indicated by $* * *$, and $* * *$, respectively. All models report standard errors that are robust to an unknown form of heteroskedasticity and clustered at the household level.
} 


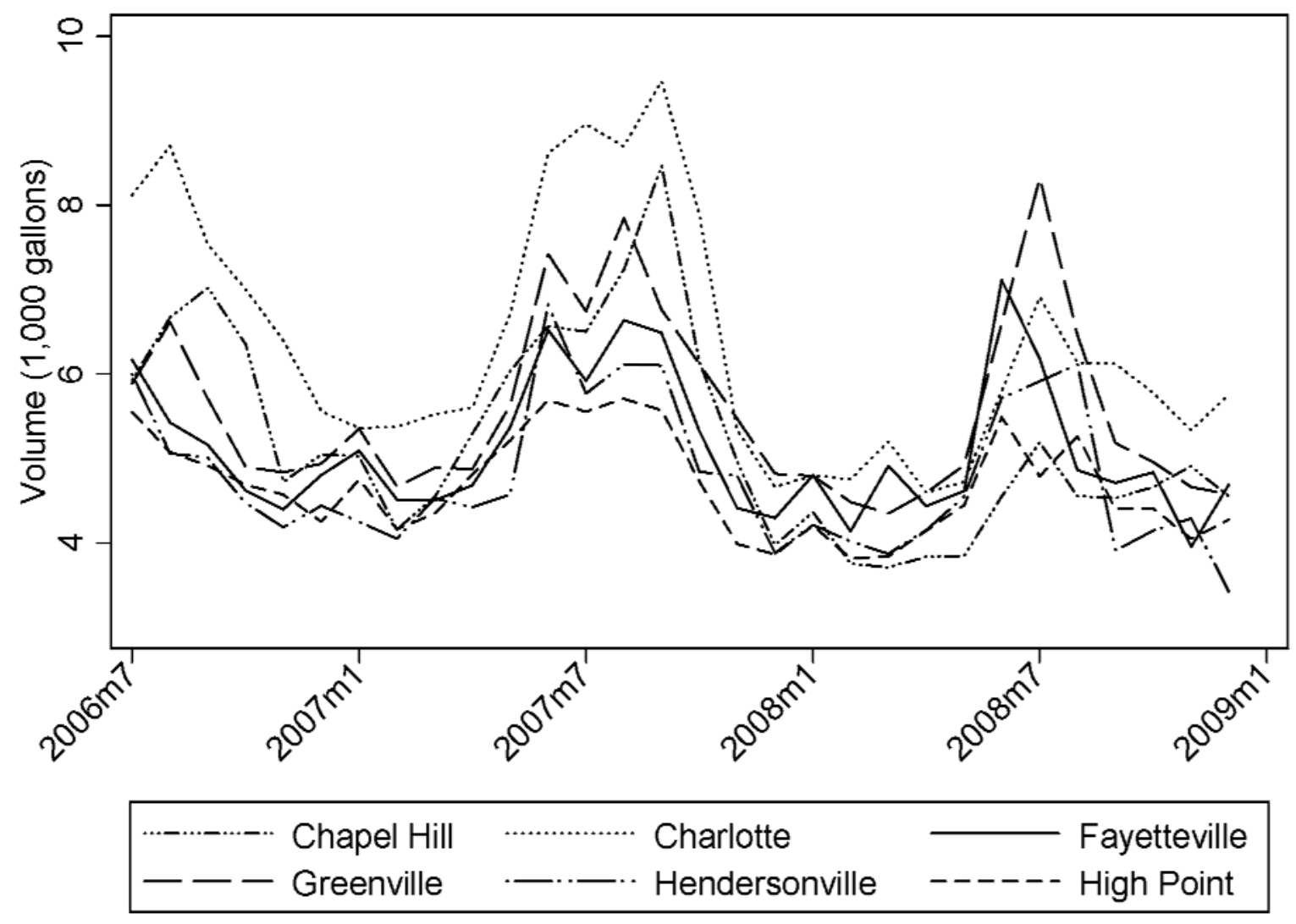

Figure 1. Mean per-capita consumption over time (1,000 gallons). 


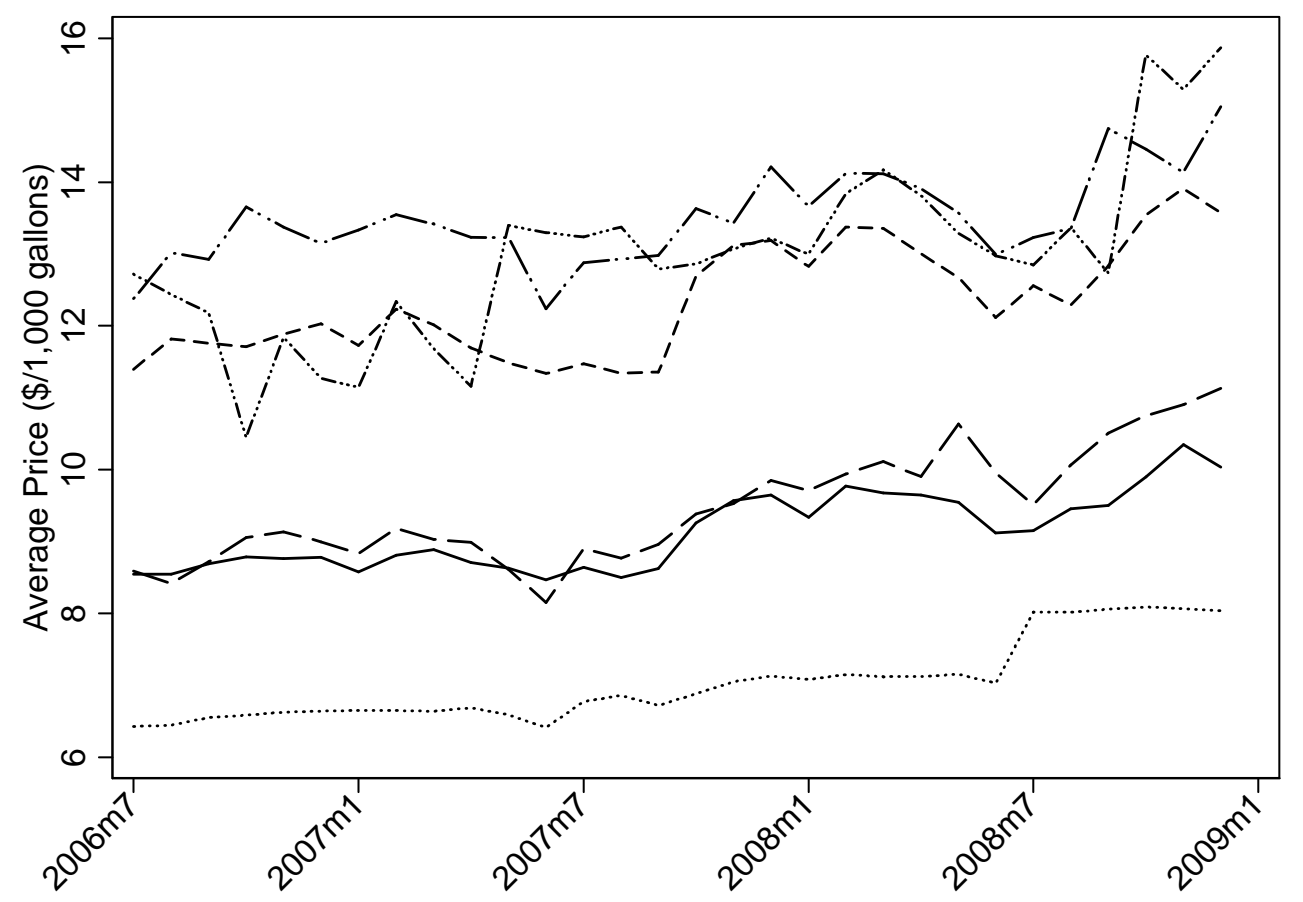

Panel A. Monthly Mean Average Price per 1,000 gallons consumed.

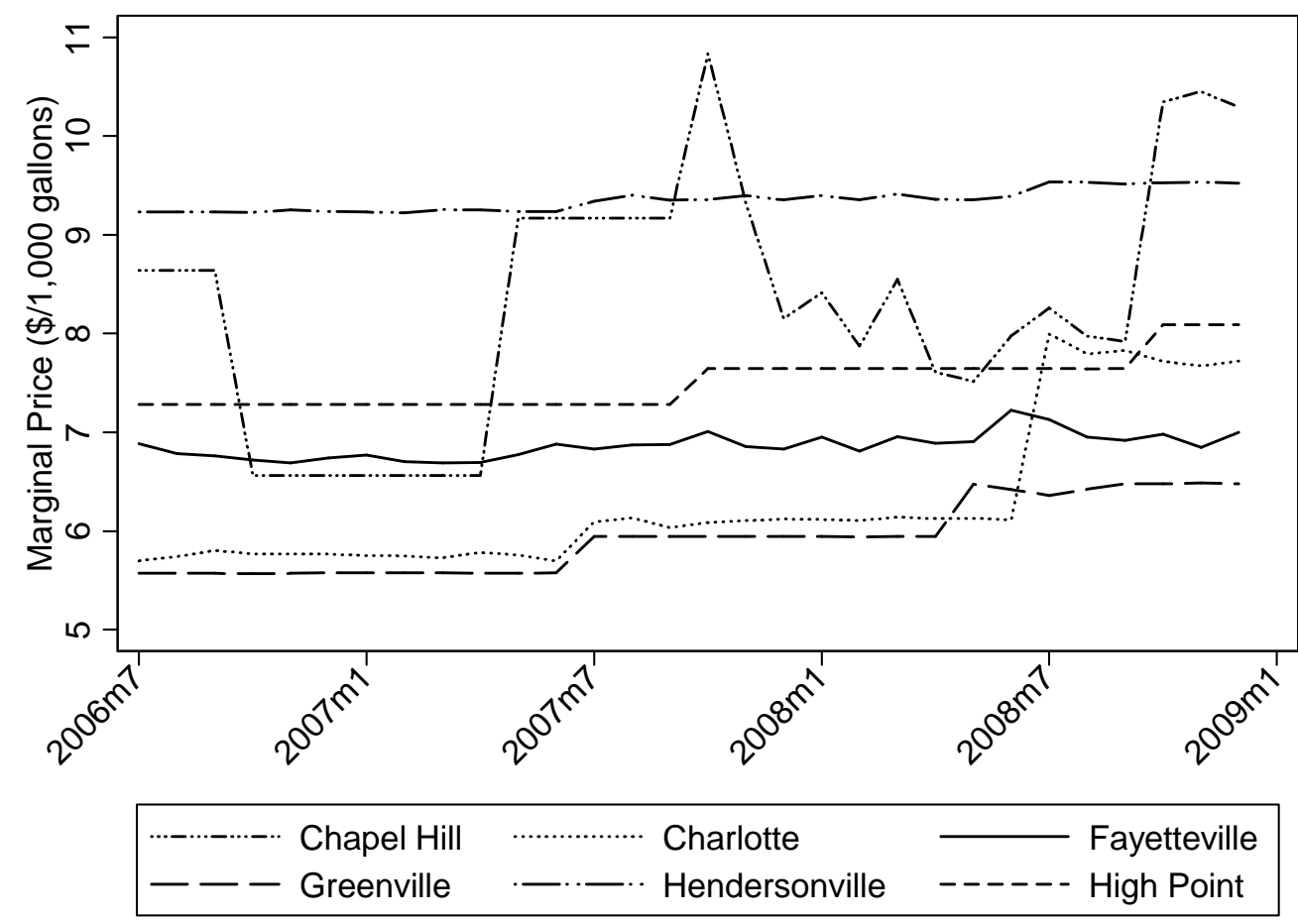

Panel B: Monthly Mean Marginal Price for Last 1,000 Gallons Consumed.

Figure 2. Mean Monthly Average and Marginal Prices. 